\title{
A trace fossil made by a walking crayfish or crayfish-like arthropod from the Lower Jurassic Moenave Formation of southwestern Utah, USA
}

\author{
Makae Rose $^{1}$, Jerald D Harris ${ }^{\text {Corresp., } 2}$, Andrew RC Milner ${ }^{3}$ \\ ${ }^{1}$ Department of Biology, Dixie State University, St. George, UT, United States \\ 2 Department of Physical Sciences, Dixie State University, St. George, UT, United States \\ ${ }^{3}$ St. George Dinosaur Discovery Site at Johnson Farm, St. George, UT, United States \\ Corresponding Author: Jerald D Harris \\ Email address: jharris@dixie.edu
}

New invertebrate trace fossils from the Lower Jurassic Moenave Formation at the St. George Dinosaur Discovery Site at Johnson Farm (SGDS) continue to expand the ichnofauna at the site. A previously unstudied arthropod locomotory trace, SGDS 1290, comprises two widely spaced, thick, gently undulating paramedial impressions flanked externally by small, tapered to elongate tracks with a staggered to alternating arrangement. The specimen is not a variant of any existing ichnospecies, but bears a striking resemblance to modern, experimentally generated crayfish walking traces, suggesting a crayfish or crayfish-like maker for the fossil. Because of its uniqueness, we place it in a new ichnospecies, Siskemia eurypyge. It is the first fossil crayfish or crayfishlike locomotion trace ever recorded. 
1 A trace fossil made by a walking crayfish or crayfish-like 2 arthropod from the Lower Jurassic Moenave Formation of 3 southwestern Utah, USA

4

5 Makae Rose ${ }^{1}$, Jerald D. Harris ${ }^{2}$, and Andrew R.C. Milner ${ }^{3}$

$6 \quad{ }^{1}$ Department of Biology, Dixie State University, St. George, UT, 84770, USA

$7 \quad 2$ Department of Physical Sciences, Dixie State University, St. George, UT, 84770, USA

$8 \quad{ }^{3}$ St. George Dinosaur Discovery Site at Johnson Farm, St. George, UT, 84790, USA

10 Corresponding Author:

11 Jerald D. Harris

12225 South 700 East, St. George, UT, 84770, USA

13 Email address: jharris@dixie.edu 


\section{Abstract}

New invertebrate trace fossils from the Lower Jurassic Moenave Formation at the St. George Dinosaur Discovery Site at Johnson Farm (SGDS) continue to expand the ichnofauna at the site. A previously unstudied arthropod locomotory trace, SGDS 1290, comprises two widely spaced, thick, gently undulating paramedial impressions flanked externally by small, tapered to elongate tracks with a staggered to alternating arrangement. The specimen is not a variant of any existing ichnospecies, but bears a striking resemblance to modern, experimentally generated crayfish walking traces, suggesting a crayfish or crayfish-like maker for the fossil. Because of its uniqueness, we place it in a new ichnospecies, Siskemia eurypyge. It is the first fossil crayfish or crayfish-like locomotion trace ever recorded.

\section{Introduction}

Paleoichnology, the study of ichnofossils (fossil tracks and traces), contributes a substantial body of paleobiological information to the understanding of extinct organisms. This is because ichnofossils are direct results of ancient animal behavior (Osgood, 1975) that could only otherwise be inferred from body fossils. Furthermore, the global commonness of ichnofossils compared to body fossils means that the ichnological record often can preserve evidence of the presence of organisms not otherwise or poorly represented in the body fossil record (Osgood, 1975), especially of invertebrates that lack hard parts and therefore fossilize only under exceptional conditions. Except for conchostracans (sensu Kozur \& Weems, 2010) and ostracods, which have biomineralized carapaces, arthropods, when compared to their evolutionary diversity, are among the less commonly preserved body-fossil components of terrestrial (including freshwater) paleoecosystems except in various Konservat-Lagerstätten (fossiliferous sites of exceptional preservational quality) (e.g., Charbonnier et al., 2010; Luque et al., 2019; Selden \& Nudds, 2012; Smith, 2012). Yet from the mid-Paleozoic through the Cenozoic, arthropods - especially insects and arachnids - were certainly the most populous and diverse metazoan components of most terrestrial ecosystems (Labandeira \& Beall, 1990), and their paleoecological importance cannot be underestimated.

Arthropod ichnofossils can be more common and abundant than arthropod body fossils, and may indicate the presences of various arthropod taxa in terrestrial paleoecosystems for which body fossils may be entirely absent. Burrows (domichnia) made by arthropods comprise one such body of evidence. For example, several burrow ichnotaxa in eolian sandstones have been attributed to arthropods (Ekdale, Bromley \& Loope, 2007). Some Macanopsis, Psilonichnus, and Skolithos burrows may have been made by spiders (Uchman, Vrenozi \& Muceku, 2018); other Psilonichnus have been attributed to crabs (Curran, Savarese \& Glumac, 2016). Camborygma burrows, attributed to crayfish (Hasiotis \& Mitchell, 1993), are the primary body of evidence for crayfish in the fossil record. Perhaps more familiarly, walking tracks (repichnia) of arthropods have an extensive geological history, spanning from the Cambrian (and possibly latest Precambrian [Chen et al., 2018]) through the Holocene (e.g., Eiseman \& Charney, 2010). They 
constitute some of the earliest evidence of metazoan life venturing onto land (reviewed in Minter et al., 2016a; Minter et al., 2016b) and are known from virtually every paleoenvironment, from near shore and shallow marine environments (e.g., Collette, Hagadorn \& Lacelle, 2010; MacNaughton et al., 2002; Pirrie, Feldmann \& Buatois, 2004; Shillito \& Davies, 2018; Trewin \& McNamara, 1994) and, terrestrially, from proglacial systems (e.g., Anderson, 1981; Lima, Minter \& Netto, 2017; Lima et al., 2015; Uchman, Kazakauskas \& Gaigalas, 2009; Walter, 1985 ) to desert ergs (e.g., Gilmore, 1927; Good \& Ekdale, 2014; Sadler, 1993).

The St. George Dinosaur Discovery Site at Johnson Farm (SGDS) in St. George, Washington County, Utah (Fig. 1) has been called a Konzentrat-Ichnolagerstätte (Hunt \& Lucas, 2006a) because of its exceptional concentration of well-preserved ichnofossils from a broad spectrum of terrestrial organisms. The site preserves a detailed "snapshot" of an earliest Jurassic ecosystem from on- and offshore portions of a freshwater, lacustrine paleoenvironment. The "Dinosaur Discovery" part of the name of the site indicates the concentration of dinosaur tracks at this locality (Milner, Lockley \& Johnson, 2006; Milner, Lockley \& Kirkland, 2006; Milner et al., 2009), but tracks of other vertebrates (Lockley, Kirkland \& Milner, 2004; Milner, Lockley \& Johnson, 2006) and a moderately diverse invertebrate ichnofauna (Lucas et al., 2006a) are also preserved. Burrows pertaining to Helminthoidichnites, Palaeophycus, and Skolithos are abundant at the site, but locomotory trackways made by arthropods, referred to cf. Bifurculapes, Diplichnites, and cf. Kouphichnium, are also present. Ichnospecies of Bifurculapes have been variably attributed to insects, possibly beetles, and to crustaceans (Getty, 2016, 2018; Hitchcock, 1858, 1865); ichnospecies of Diplichnites have been attributed to myriapods (Briggs, Rolfe \& Brannan, 1979; Davis, Minter \& Braddy, 2007; Pollard, Selden \& Watts, 2008; Shillito \& Davies, 2018), notostracans (Lucas et al., 2006a; Minter et al., 2007), and other arthropods (Melchor \& Cardonatto, 2014; Minter et al., 2007); and ichnospecies of Kouphichnium have been attributed to limulids (Caster, 1944; King, Stimson \& Lucas, 2019; Lomax \& Racay, 2012).

A previously unstudied SGDS specimen, SGDS 1290, is an arthropod locomotory trace that differs markedly from any other SGDS specimen, indicating the presence of a heretofore unrecognized component of the SGDS ichnofauna. SGDS 1290 is an arthropod locomotory trace because it includes distinct footprints in a discernible cycle, but lacks any features of vertebrate tracks, such as distinct toes (sensu Seilacher, 2007). The trace thus resembles numerous other fossil traces attributed to arthropods, as well as those generated experimentally. The fossil was discovered and collected March 11, 2010 by SGDS volunteer Jon Cross.

\section{Geological Setting}

Most of the fossils preserved at the SGDS, including the ichnofossil described below, occur in the Whitmore Point Member of the Moenave Formation (Kirkland \& Milner, 2006; Kirkland et al., 2014), which conformably overlies the Dinosaur Canyon Member of the Moenave Formation and disconformably underlies the Springdale Sandstone Member, which itself has been assigned as both the lowest member of the Kayenta Formation (Lucas \& Tanner, 2006) and the uppermost member of the Moenave Formation (Steiner, 2014a). The richest source 
94

95

96

97

98

99

100

101

102

103

104

105

106

107

108

109

110

111

112

113

114

115

116

117

118

119

120

121

122

123

124

125

126

127

128

129

130

131

132

133

of the ichnofossils at the SGDS, again including the trace described below, occur within a finegrained sandstone near the base of the Whitmore Point Member initially called the "Main Track Layer" (Kirkland \& Milner, 2006; Milner, Lockley \& Johnson, 2006; Milner, Lockley \& Kirkland, 2006) and, later and more formally, the Johnson Farm Sandstone Bed (unit 40 of Kirkland et al., 2014) (Fig. 2). SGDS 1290 comes from the uppermost strata of this unit, specifically one of several thinly bedded, apparently conformable, fine-grained-sandstone "Top Surface Tracksite" horizons (sensu Kirkland et al., 2014; Milner, Lockley \& Johnson, 2006; Milner, Lockley \& Kirkland, 2006). The Whitmore Point Member preserves sediments deposited in and around the large, freshwater Lake Whitmore (formerly called Lake Dixie) (Kirkland \& Milner, 2006; Kirkland et al., 2014); at the SGDS itself, the Johnson Farm Sandstone Bed preserves ichnofossils and sedimentary structures made in both subaerial and subaqueous conditions, indicating a shoreline paleoenvironment (Milner, Lockley \& Kirkland, 2006). Ichnologically, invertebrate ichnofossils in this paleoenvironment pertain to the Scoyenia ichnofacies (Buatois \& Mángano, 2004; Lucas et al., 2006a), while the associated vertebrate ichnofauna pertains to the Eubrontes ichnocoenosis of the Grallator ichnofacies (Hunt \& Lucas, 2006b; Hunt \& Lucas, 2006c).

Age determinations for the Whitmore Point Member have varied. The unit typically has been placed entirely within the Hettangian (earliest Jurassic) largely on biostratigraphic grounds (see discussions in Kirkland et al., 2014; Milner et al., 2012; Parrish et al., 2019; and Tanner \& Lucas, 2009), but was also determined to straddle the Triassic-Jurassic boundary $(201.3 \pm 0.2$ $\mathrm{Ma}$ ) on magnetostratigraphic grounds (Donohoo-Hurley, Geissman \& Lucas, 2010), in which system the Johnson Farm Sandstone Bed would be Rhaetian (latest Triassic) in age. However, Steiner (2014b) recovered Hettangian paleomagnetic sequences from the Whitmore Point Member, and Suarez et al. (2017) calibrated the magnetostratigraphic data of Donohoo-Hurley, Geissman \& Lucas (2010) with high-precision U-Pb dates to re-situate the Triassic-Jurassic boundary stratigraphically farther down in the Dinosaur Canyon Member of the Moenave Formation, also making the Whitmore Point Member entirely earliest Jurassic in age. The Johnson Farm Sandstone Bed and its fossils therefore are Hettangian in age, approximately 200 million years old.

\section{Materials \& Methods}

Ichnological terminology for arthropod locomotory traces used herein follows Minter, Braddy \& Davis (2007) and Genise (2017). Minter, Braddy \& Davis (2007) defined "tracks" as discrete marks made by locomotory appendages, "impressions" as continuous traces made by another portion of the anatomy of a trace maker, and "imprints" as discontinuous such traces; they also provided terms for trackway arrangement and measurements. Genise (2017) outlined various descriptive terms for individual track morphologies. Measurements of SGDS 1290 (Fig. 3C, Table 1) were taken using digital calipers. The measurements were: track length and width, internal and external widths between paramedial impressions, distances between tracks and adjacent paramedial impressions, and widths of left and right paramedial impressions. 
134 Measurements pertaining to the paramedial impressions were taken adjacent to individual

135

136

137

138

139

140

141

142

143

144

145

146

147

148

149

150

151

152

153

154

155

156

157

158

159

160

161

162

163

164

165

166

167

168

169

170

171

172

173 tracks/track sets.

The electronic version of this article in Portable Document Format (PDF) will represent a published work according to the International Commission on Zoological Nomenclature (ICZN), and hence the new names contained in the electronic version are effectively published under that Code from the electronic edition alone. This published work and the nomenclatural acts it contains have been registered in ZooBank, the online registration system for the ICZN. The ZooBank LSIDs (Life Science Identifiers) can be resolved and the associated information viewed through any standard web browser by appending the LSID to the prefix http://zoobank.org/. The LSID for this publication is: urn:lsid:zoobank.org:pub:D78963CE-11C8-4447-8E26BBCCF0E37143. The LSID for the herein described Siskemia eurypyge isp. nov. is: urn:lsid:zoobank.org:act:769B0815-8991-4F0E-B32C-99C87A9D293B. The online version of this work is archived and available from the following digital repositories: PeerJ, PubMed Central and CLOCKSS.

\section{Description of SGDS 1290}

SGDS 1290, a natural cast (convex hyporelief), consists of two parallel, undulating, paramedial ridges flanked externally by eight sets of small tracks that range in shape from ovoid to tapered (teardrop-shaped) to elongate (Fig. 3A, B). Tracks within each set are closely appressed; track sets are, however, spaced well apart from one another. The track sets are oriented perpendicular to the trackway axis, though tapered and elongate individual tracks within each set have long axes that parallel or are oblique to the trackway axis. Track sets average 4.5 $\mathrm{mm}$ long anteroposteriorly and $5.4 \mathrm{~mm}$ wide mediolaterally (Table 1). Left (L) and right (R) sets of tracks are arranged in an alternating pattern. Based on Fairchild \& Hasiotis (2011), the tapering ends of the tapered tracks are presumed to be anterior reflectures, indicating the direction of movement. Most tracks have long axes oriented parallel to the trackway axis; a few (such as in sets L1, L4, and R2) are oblique to the axis. Track R1 is markedly elongate rather than tapered, but also parallel to the trackway axis. Track sets L1, L3, and R4 consist of three distinct but appressed tracks; sets L2, L4, and R2 consist of pairs of appressed tracks, and R1 and R3 appear to consist of single tracks, although the possibility that each comprises multiple, conjoined tracks cannot be ruled out.

The paramedial impressions typically are thick mediolaterally, though they vary and taper briefly to nothingness in a few places (being more continuous than repeating, we consider them "impressions" and not "imprints"). The impressions follow gently undulating (non-linear and low amplitude) pathways. They span approximately $7.5 \mathrm{~cm}$ along the slab of rock. Overprints of short segments of the paramedial impressions that are not accompanied by tracks are visible behind the main trace segment on a slightly higher stratum. The impressions vary in width along their lengths, ranging from 0-3.1 mm (mean $=2.0 \mathrm{~mm})$ for the left impressions and 0-3.0 $\mathrm{mm}$ $($ mean $=1.6 \mathrm{~mm})$ for the right (Table 1). The width of the trace from left impression to right impression averages $9.4 \mathrm{~mm}$ when measured from the lateral (external) edges and $5.6 \mathrm{~mm}$ when 
174

175

176

177

178

179

180

181

182

183

184

185

186

187

188

189

190

191

192

193

194

195

196

197

198

199

200

201

202

203

204

205

206

207

208

209

210

211

212

213

measured between the medial (internal) edges (Table 1). The distances between the impressions

thus are greater than the distances between the impressions and their flanking tracks (mean $=1.6$ $\mathrm{mm}$ ); the ratio of the distance between a paramedial impression and its flanking track to the distance between the medial edges of the paramedial impressions ranges from 0-0.78 (mean = 0.31; see Supplemental Material), so on average, the paramedial impressions are roughly three times farther apart from each other than either is from its flanking tracks. The impressions taper slightly in cross sectional view: they are wider at their bases and narrower at their rounded apices.

\section{Comparisons to Arthropod Repichnial Ichnotaxa}

\section{Arthropod repichnia lacking medial or paramedial impressions}

Several arthropod locomotory (walking) ichnotaxa are readily distinguished from SGDS 1290 by (usually) lacking medial or paramedial impressions, but are worth comparing to SGDS 1290 to ascertain whether or not it might be a morphological variant of such ichnotaxa. These ichnotaxa are Acanthichnus (Hitchcock, 1858), Asaphoidichnus (Miller, 1880), Bifurculapes (Hitchcock, 1858), Coenobichnus (Walker, Holland \& Gardiner, 2003), Copeza (Hitchcock, 1858), Danstairia congesta (Smith, 1909), Diplichnites (Dawson, 1873), Eisenachichnus (Kozur, 1981), Foersterichnus (Pirrie, Feldmann \& Buatois, 2004), Hamipes (Hitchcock, 1858), Laterigradus (de Carvalho et al., 2016), Lithographus (Hitchcock, 1858), Hornburgichnium (Kozur, 1989), Maculichna (Anderson, 1975a), Merostomichnites (Packard, 1900), Mirandaichnium (Aceñolaza, 1978), Octopodichnus (Gilmore, 1927), Petalichnus (Miller, 1880), Pterichnus (Hitchcock, 1865), Tasmanadia (Chapman, 1929), and Umfolozia (Savage, 1971). Most of these ichnotaxa further differ from SGDS 1290 in the shapes and configurations of their tracks. The comparisons below specify track-making taxa only when one or more have been proposed for the ichnotaxon.

Acanthichnus tracks (Fig. 4A), attributed to a chelicerate such as a solifugid, are oppositely arranged, short, elongate impressions in two (or four, per Dalman \& Lucas, 2015) parallel rows; tracks either are parallel to or angle slightly away from the trackway axis (Dalman \& Lucas, 2015; Hitchcock, 1858). This morphology and organization are both unlike those of SGDS 1290.

Asaphoidichnus tracks (Fig. 4B), attributed to trilobites, are elongate to crescentic, possess 3-4 crescentic branches at one end, and are oriented oblique to the trackway axis (Miller, 1880). They are far more complex in structure than the tracks of SGDS 1290.

Bifurculapes (Fig. 4C), attributed to an insect, possibly a beetle (Getty, 2016), comprises adjacent pairs (rarely triplets) of slightly staggered, elongate, straight to crescentic tracks that lie parallel or slightly oblique to the trackway axis, unlike the tracks of SGDS 1290. Tracks in each pair sometimes converge toward one end in Bifurculapes. This ichnotaxon typically does not possess paramedial impressions, but a specimen described by Getty (2016: fig. 1) possess two such traces, albeit faintly, that lie closer to the tracks than to the trackway axis, as in SGDS 1290. These impressions are far less pronounced than their associated tracks, unlike those of SGDS 
214 1290. Getty (2020) ascertained that Bifurculapes traces were made subaqueously and may have

215

216

217

218

219

220

221

222

223

224

225

226

227

228

229

230

231

232

233

234

235

236

237

238

239

240

241

242

243

244

245

246

247

248

249

250

251

252

been made by a terrestrial insect that would have left different tracks subaerially.

Coenobichnus tracks (Fig. 4D), attributed to a hermit crab, are thick, crescentic to ellipsoidal, roughly parallel and closely appressed to the trackway axis, and asymmetrical, with the left tracks larger than the right tracks (Walker, Holland \& Gardiner, 2003), all of which differentiate this ichnotaxon from SGDS 1290.

Copeza (possibly a variant and synonym of Lithographus [Lull, 1953; Rainforth, 2005]; Fig. 4E) consists of triplets of roughly oppositely arranged, linear, elongate tracks in which the anteriormost lies roughly perpendicular to the trackway axis while the posteriormost pairs lie parallel or oblique to the trackway axis (Lull, 1953). This rare ichnotaxon is thus unlike SGDS 1290.

Danstairia congesta (Fig. 4F) comprises circular to crescentic tracks in closely appressed sets of up to six that are oriented oblique to the trackway axis; tracks often overlap to form Vshaped structures (Walker, 1985), unlike in SGDS 1290.

Diplichnites (possibly including Acripes per Häntzschel [1975] and Hammersburg, Hasiotis \& Robison [2018]; also see below) tracks span a range of morphologies. D. aenigma (Fig. 4G), ostensibly the ichnospecies lectotype except that no specimen was designated as such (Stimson et al., 2018), typically comprises elongate, closely packed tracks in parallel rows on either side of the trackway axis; the tracks lie perpendicular to the trackway axis (Dawson, 1873). D. gouldi Type A (Fig. 4H) comprises parallel rows of closely spaced, oppositely arranged, simple, roughly circular to oblong to comma-shaped or irregular tracks with varying orientations to the trackway axis; D. gouldi Type B comprises closely spaced, elongate impressions oriented perpendicular, or nearly so, to the trackway axis, matching the general description of D. aenigma; $D$. gouldi Type $\mathrm{C}$ is similar to Type $\mathrm{B}$, but the tracks are oriented oblique $\left(\sim 45^{\circ}\right)$ to the trackway axis (Trewin \& McNamara, 1994). D. cuithensis, attributed to large arthropleurid myriapods, is similar to both $D$. aenigma and D. gouldi Type B, but is very large and has widely spaced rows of tracks (Briggs, Rolfe \& Brannan, 1979). D. binatus tracks often occur as closely appressed pairs of imprints (Webby, 1983). D. triassicus tracks are small and circular to ovoid rather than elongate, and frequently paired on either side of the trackway axis (e.g., Pollard, Selden \& Watts, 2008); this ichnospecies has been alternately suggested to be a synonym of D. gouldi (e.g., Lucas et al., 2006b) or to pertain to Acripes (e.g., Machalski \& Machalska, 1994; Pollard, 1985). D. metzi possesses a midline impression that is sometimes interrupted by connections between tracks in the closely appressed rows (Fillmore et al., 2017). The ichnogenus is in need of thorough review (Smith et al., 2003), but in all cases, the tracks are of different morphologies and arrangements than those of SGDS 1290.

Eisenachichnus tracks (Fig. 4I) are elongate, paired, and oblique to the trackway axis (rarely perpendicular), but the patterns of the pairs on either side of the trackway axis normally are asymmetrical: on one side, the paired tracks lie end to end, while on the other, they are more adjacent (Kozur, 1981). This morphology and arrangement are unlike those of SGDS 1290.

Peer) reviewing PDF | (2020:09:52634:1:1:NEW 19 Nov 2020) 
253

254

255

256

257

258

259

260

261

262

263

264

265

266

267

268

269

270

271

272

273

274

275

276

277

278

279

280

281

282

283

284

285

286

287

288

289

290

291

Foersterichnus (Fig. 4J), attributed to a crab, consists of widely spaced, paired rows of elongate tracks in sets of 3-4; rows are parallel to oblique to the trackway axis, and tracks in each set frequently overlap (Pirrie, Feldmann \& Buatois, 2004). The wide spacing, clustering of tracks, and orientations of the tracks are unlike those of SGDS 1290.

Hamipes tracks (Fig. 4K) consist of closely spaced, paired, elongate to crescentic impressions oriented parallel to the trackway axis; the outer tracks are longer than their accompanying inner tracks, and the tracks are staggered or alternately arranged (Getty, 2018; Hitchcock, 1858). Track morphology readily differentiates Hamipes from SGDS 1290.

Laterigradus tracks (Fig. 4L), attributed to sideways-walking crabs, comprises asymmetrical trackways consisting of sets of up to four tracks (de Carvalho et al., 2016). Individual tracks vary widely in shape, ranging from elongate to tapered to comma-shaped to roughly circular. Track sets fall within a narrow trackway width and exhibit different stride lengths along the course of a trackway. While some individual track shapes resemble those of SGDS 1290, the overall arrangement and layout of the tracks is distinct.

Lithographus (including Permichnium sensu Minter \& Braddy, 2009) tracks (Fig. 4M), which match those made by pterygote insects, especially extant cockroaches (Davis, Minter \& Braddy, 2007), comprise trios (or pairs, in the case of the Permichnium variant) of elongate to comma-shaped, rather than circular or tapering, tracks that are arranged at different angles to one another, some of which are oriented perpendicular to the trackway axis, and others of which are oblique to the trackway axis (Guthörl, 1934; Hitchcock, 1858; Minter \& Braddy, 2009). These track morphologies and arrangements are distinct from those of SGDS 1290. Hornburgichnium reportedly is similar to Permichnium, but has three tracks on either side of the midline instead of two, and at least one of each set is oriented parallel to the trackway axis (Kozur, 1989); it may also be a variant of Lithographus (Lucas et al., 2005a). Trackways of Lithographus can transition into trackways that Hitchcock (1858) called Hexapodichnus (Davis, Minter \& Braddy, 2007; Minter, Braddy \& Davis, 2007), so the latter may be considered a behavioral and/or substrateconsistency variant of the former, and also unlike SGDS 1290.

Maculichna (including Guandacolichnus and Paganzichnus of Pazos [2000] per Buatois \& Mángano [2003]) tracks (Fig. 4N) comprise pairs (sometimes more) of small, circular to slightly elongate tracks arranged in closely appressed, slightly staggered rows. Pairings are oriented virtually parallel to the trackway axis (Anderson, 1975a); occasionally, short segments of linear, singular medial or closely spaced, paired paramedial imprints are also preserved that can be offset to one side of the trackway axis (Anderson, 1975a: fig. 8b, d, e). The pairing of Maculichna tracks differs from that of SGDS 1290. Aceñolaza \& Buatois $(1991,1993)$ and Archer \& Maples (1984) described Maculichna traces that exhibit the pairing of classic Maculichna from South Africa, but in which tracks are more ellipsoidal to shaped like slightly inflated isosceles triangles; the long axes of the triangles are oriented close to perpendicular to the trackway axis. Pazos (2000) recognized this morphology as the separate ichnotaxon Paganzichnus. This morphology is also unlike that of SGDS 1290. 
292

293

294

295

296

297

298

299

300

301

302

303

304

305

306

307

308

309

310

311

312

313

314

315

316

317

318

319

320

321

322

323

324

325

326

327

328

329

330

331

The ichnospecies holotype of Merostomichnites narragansettensis (Fig. 4O) consists of parallel rows of roughly oppositely arranged circular to elongate to comma-shaped tracks whose long axes are perpendicular to the trackway axis (Packard, 1900). Merostomichnites beecheri tracks are circular and connected across the trackway axis by curvilinear, shallow, M-shaped imprints, creating a sort of segmented midline impression (Packard, 1900: fig. 4). These track and trace morphologies do not match those of SGDS 1290.

Mirandaichnium (Fig. 4P) consists of two rows of elongate, linear tracks that terminate laterally in small, circular impressions. Tracks are oriented perpendicular or oblique to the trackway axis, oppositely situated, and often grouped into series of eight (Aceñolaza \& Buatois, 1993; Buatois et al., 1998), unlike those of SGDS 1290.

Octopodichnus (Fig. 4Q) ichnospecies, attributed to arachnids, have different morphologies. $O$. didactylus tracks are circular to crescentic to bifurcate or trifurcate oriented parallel to the trackway axis in alternating, arcuate sets of four (Sadler, 1993). O. minor tracks have a similar organization, but the tracks are more amorphous; $O$. raymondi tracks consist of clusters of four circular to crescentic marks arranged in checkmark-like patterns (Sadler, 1993). These track morphologies and distinctive arrangements are substantially unlike those of SGDS 1290.

Petalichnus (Fig. 4R), attributed to trilobites (Braddy \& Almond, 1999), comprises sets of 2-3 elongate to crescentic tracks oriented perpendicular to the trackway axis (Miller, 1880). Anderson (1975b) and Braddy \& Almond (1999) diagnosed Petalichnus tracks as sometimes bifurcate and occurring in series of 9-12; they further noted that the ichnotaxon needs review. Both track morphology and organization are unlike those of SGDS 1290.

Pterichnus tracks (Fig. 4S), attributed to isopods, frequently are segmented and are more linear and elongate than any in SGDS 1290. Tracks (or series of segments) are oriented oblique (Types 1 and 2 of Gaillard et al., 2005) or parallel (Types 3 and 4 of Gaillard et al., 2005) to the trackway axis, and approximately symmetrically arranged in two parallel rows (Gaillard et al., 2005; Hitchcock, 1865) that are somewhat closer together than are those of the morphologically similar Diplichnites. Types 3 and 4 of Gaillard et al. (2005) morphologically grade into Diplopodichnus (Uchman et al., 2011). Hammersburg, Hasiotis \& Robison (2018) suggested that Pterichnus comprises undertracks of Lithographus and is thus a junior synonym of that ichnotaxon. In any case, Pterichnus tracks are readily distinguished from SGDS 1290.

Tasmanadia traces (Fig. 4T) consist of two rows of closely packed, elongate, linear tracks oriented generally perpendicular to the trackway axis; occasionally, tracks overlap at one end, creating narrow, V-shaped structures (Chapman, 1929; Glaessner, 1957). Morphologically, this ichnotaxon resembles Diplichnites gouldi Type B and Umfolozia (but lacks the organization of the latter), and differs from SGDS 1290 for the same reasons as those ichnotaxa.

Umfolozia (Fig. 4U), attributed to syncarid and peracarid crustaceans (Lima, Minter \& Netto, 2017; Savage, 1971), consists of parallel rows of irregularly shaped to crescentic tracks oriented perpendicular or oblique to the trackway axis that follow a unique repeating pattern (Anderson, 1981; Savage, 1971) unlike anything discernible in SGDS 1290. Aceñolaza \& 
332 Buatois (1993) noted morphological similarities between Mirandaichnium, Tasmanadia, and

333

334

335

336

337

338

339

340

341

342

343

344

345

346

347

348

349

350

351

352

353

354

355

356

357

358

359

360

361

362

363

364

365

366

367

368

369

370

371

Umfolozia and postulated similar track makers.

In summary, SGDS 1290 is not a variant of any of these ichnotaxa.

\section{Arthropod repichnia possessing one medial impression}

Several other arthropod locomotory (walking) ichnotaxa are also readily distinguished from SGDS 1290 by possessing singular medial, rather than paired paramedial, impressions; again, comparison is warranted to ascertain whether or not SGDS 1290 is a morphological variant of such ichnotaxa. These ichnotaxa are Kouphichnium (Caster, 1938; Nopcsa, 1923), “Merostomichnites isp." (Hanken \& Stormer, 1975), Oniscoidichnus (Brady, 1947, 1949), Palmichnium (Richter, 1954), Paleohelcura (Gilmore, 1926), Protichnites (Owen, 1852), Robledoichnus (Kozur \& Lemone, 1995), Shalemichnus (Kozur \& Lemone, 1995), Stiallia (Smith, 1909), and Stiaria (Smith, 1909). As with traces lacking any medial impressions, these ichnotaxa further differ from SGDS 1290 in track morphology. As before, possible track makers are specified only when available.

Kouphichnium traces (Fig. 4V) are attributed to limulids and occur in a variety of configurations. Tracks in clear Kouphichnium walking traces that possess singular medial impressions (e.g., many K. lithographicum, but not, for example, K. minkinensis [King, Stimson \& Lucas, 2019; q.v. Gaillard, 2011a; Shu et al., 2018]) typically occur in sets of up to five in rows oriented oblique to the medial impression and trackway axis; individual tracks range from circular and ellipsoidal to elongate, and can split into anywhere from 2-5 branches at their ends (Caster, 1938, 1944; King, Stimson \& Lucas, 2019; Shu et al., 2018). Well-preserved Kouphichnium tracks are dissimilar to those of SGDS 1290.

Traces referred to as "Merostomichnites" (Fig. 4W) and attributed to the eurypterid Mixopterus by Hanken \& Stormer (1975) consist of three elongate and crescentic tracks in oblique rows on either side of an intermittent medial impression; the tracks increase in size laterally, and some split into two or more branches on one end. In any of these cases, however, the tracks are substantially more complex than those of SGDS 1290.

Oniscoidichnus tracks (Fig. 4X) are elongate to crescentic, oriented perpendicular or oblique to the trackway axis, closely packed and closely appressed to the single midline impression (Brady, 1947; Davies, Sansom \& Turner, 2006). In all these details, Oniscoidichnus traces differ markedly from SGDS 1290.

Ichnospecies of Palmichnium (Fig. 4Y), also attributed to eurypterids, vary in morphology. Generally, they comprise complex sets of tracks lying lateral to a medial impression that can be either continuous or discontinuous. Tracks range in shape from elongate to crescentic to ovoid to chevron shaped, and they generally parallel the trackway axis. The tracks occur in oblique rows in sets of up to four; in some traces, the lateralmost tracks are elongate and curved, while the more medial tracks are linear and oriented parallel to the trackway axis (Braddy \& Milner, 1998; Minter \& Braddy, 2009; Poschmann \& Braddy, 2010; Richter, 1954). Tracks are both more numerous and differently shaped than those of SGDS 1290.

Peer) reviewing PDF | (2020:09:52634:1:1:NEW 19 Nov 2020) 
Paleohelcura (including Mesichnium per Braddy [1995] and Triavestigia per Kozur, Löffler \& Sittig [1994]; possibly a junior synonym of Stiaria; Fig. 4Z) traces, attributed to scorpions (Brady, 1947; Davis, Minter \& Braddy, 2007), comprise small, circular tracks in sets of three in either rows, triangular arrangements, or checkmark-like patterns that lie external and oblique to the medial impression (Gilmore, 1926; Lagnaoui et al., 2015; Sadler, 1993). This distinctive layout is unlike that of SGDS 1290. Peixoto et al. (2020) attributed traces lacking a medial impression and comprising closely appressed pairs or triplets of mostly elliptical tracks from the Upper Jurassic or Lower Cretaceous of Brazil to a new ichnospecies of Paleohelcura and attributed them to a pterygote insect track maker. Tracks in this ichnospecies are arranged in rows oriented oblique to the trackway axis, and track sets in this ichnospecies lie close to the midline. This morphology is also unlike that of SGDS 1290.

Protichnites traces (Fig. 4AA) comprise thick, often segmented medial impressions (sometimes absent except on trackway turns) flanked by oppositely arranged, subcircular to ellipsoidal to irregularly shaped tracks with varying orientations to the trackway axis (BurtonKelly \& Erickson, 2010; Collette, Gass \& Hagadorn, 2012; Hagadorn \& Seilacher, 2009). They differ substantially from the tracks of SGDS 1290.

Robledoichnus tracks (Fig. 4BB), attributed to flying insects, resemble tracks of Eisenachichnus but possess a discontinuous, faint medial trace consisting entirely of periodic, Vshaped marks flanked by asymmetrical pairs of tracks. On one side, the tracks are short, tapered, and oriented oblique to the trackway axis; on the other side, the tracks are longer and crescentic, oriented closer to perpendicular to the trackway axis (Kozur \& Lemone, 1995). Lucas et al. (2005b) considered Robledoichnus a probable junior synonym of Paleohelcura or Stiaria, and the ichnotaxon differs from SGDS 1290 for similar reasons as those ichnotaxa, in addition to the asymmetry.

Shalemichnus traces (Fig. 4CC), for which only half a trackway is known, consist of a straight medial impression punctuated at intervals by $\mathrm{V}$-shaped marks. This impression is flanked by sets of three tapered tracks in straight rows oriented perpendicular to the trackway axis; individual tracks have their long axes parallel to the trackway axis (Kozur \& Lemone, 1995). Minter \& Braddy (2009) considered Shalemichnus a junior synonym of Stiaria. The tracks of Shalemichnus bear some similarity to those of SGDS 1290, but the paramedial impressions of SGDS 1290 lack the V-shaped markings of the medial impression of Shalemichnus.

Stiallia traces (Fig. 4DD) consist of paired rows of long, linear impressions parallel or slightly oblique to the trackway axis and that frequently overlap. Stiallia pilosa lacks any medial or paramedial impressions, but Stiallia (Carrickia of Smith [1909]) berriana possesses a medial row of crescentic to chevron-shaped marks (Smith, 1909; Walker, 1985). Pollard (1995) suggested that Stiallia could be an arthropod swimming, rather than a walking, trace, though it also resembles traces made by bristletail insects walking in highly saturated mud (Getty et al., 2013: fig. 6F, G). Stiallia tracks are markedly unlike those of SGDS 1290. 
411

412

413

414

415

416

417

418

419

420

421

422

423

424

425

426

427

428

429

430

431

432

433

434

435

436

437

438

439

440

441

442

443

444

445

446

447

448

449

450

Stiaria tracks (including some ichnospecies of Danstairia of Smith [1909]; Fig. 4EE)), attributed to scorpionids (Braddy, 2003; Lucas, Lerner \& Voigt, 2013) and monuran insects (Genise, 2017; Kopaska-Merkel \& Buta, 2013), are oppositely situated groups of 2-4 generally circular to tapered tracks in a linear to crescentic arrangement lying roughly perpendicular to the trackway axis (Walker, 1985). In some specimens and ichnospecies of Stiaria, the singular medial impression actually varies in position, meandering from medial to almost lateral to their tracks (Fillmore, Lucas \& Simpson, 2012: fig. 26d; Walker, 1985: fig. 5b, c). In some Mississippian specimens from Pennsylvania, the medial impression is flanked by thin, discontinuous, but closely appressed paramedial imprints (Fillmore, Lucas \& Simpson, 2012: fig. 26d-g). Track arrangement alone differentiates Stiaria from SGDS 1290. Genise (2017) asserted that Stiaria should be considered a junior synonym of Siskemia (the latter has page priority over the former).

As with locomotory traces lacking medial impressions, SGDS 1290 is not a variant of any of these ichnotaxa.

\section{Arthropod repichnia possessing three or more medial and paramedial impressions}

Mitchellichnus (Fig. 4FF), attributed to archaeognathan insects (Getty et al., 2013), is distinguished from SGDS 1290 by possessing three medial impressions (Walker, 1985). Mitchellichnus tracks are complex, comprising two distinct types and arrangements. An inner set, lying close to the medial impressions, consists of apparently elongate tracks in sets of up to six that lie parallel to slightly oblique to the trackway axis; an outer set consists of larger, amorphous impressions (Walker, 1985). Tracks are thus more numerous in Mitchellichnus than in SGDS 1290, and the tracks differ in arrangement and morphology. Like Stiaria, Genise (2017) asserted that Mitchellichnus should be considered a junior synonym of Siskemia.

Keircalia (Fig. 4GG) is distinguished from SGDS 1290 by possessing four medial impressions (Smith, 1909; Walker, 1985). Keircalia tracks are crescentic to irregularly shaped, generally are oriented perpendicular to the trackway axis, and have no discernible arrangement (Walker, 1985). Both track morphology and organization are unlike those of SGDS 1290.

\section{Arthropod repichnia possessing paired paramedial impressions}

A few ichnotaxa, as well as some experimentally produced tracks of extant arthropods, resemble SGDS 1290 by possessing paired paramedial impressions in at least some specimens. Such ichnotaxa are Danstairia vagusa (Smith, 1909), Glaciichnium (Walter, 1985), Warvichnium (Walter, 1985), and Siskemia (Smith, 1909); similar extant traces include those made by notostracans (Trusheim, 1931) and crayfish (Fairchild \& Hasiotis, 2011).

Danstairia vagusa (Fig. 4HH) possesses intermittent, thin, linear imprints that do not always parallel their accompanying trackways. Tracks are circular to triangular, generally have their long axes perpendicular to the trackway axis, and lack any coherent layout (Walker, 1985), unlike those of SGDS 1290. D. vagusa somewhat resembles Keircalia traces, but its tracks are spaced more widely apart. 
451

452

453

454

455

456

457

458

459

460

461

462

463

464

465

466

467

468

469

470

471

472

473

474

475

476

477

478

479

480

481

482

483

484

485

486

487

488

489

490

Glaciichnium traces (Fig. 4II), which resemble traces made by isopods (Gibbard \& Stuart, 1974; Lima, Minter \& Netto, 2017; Uchman, Kazakauskas \& Gaigalas, 2009; Uchman et al., 2011), comprise 1-3 elongate, linear tracks ("bars" that are divided into segments [Uchman, Kazakauskas \& Gaigalas, 2009]) that lie oblique to the trackway axis and are staggered on either side of that axis, unlike the tracks of SGDS 1290; their linear, serial but discontinuous paramedial imprints are widely spaced, consistently abutting the medial ends of the tracks (Walter, 1985), farther apart than those of SGDS 1290. Walter (1985) and Lima et al. (2015) described the paramedial imprints in Brazilian specimens as comprising successive pairs of Cshaped imprints rather than strictly linear structures, further unlike SGDS 1290. Some Glaciichnium traces also possess a medial imprint as well (Uchman, Kazakauskas \& Gaigalas, 2009; Walter, 1985).

Warvichnium traces (Fig. 4JJ) are complex, comprising pairs to multiple sets of linear, discontinuous medial and paramedial imprints flanked by varying numbers of linear to crescentic tracks in two or more sets: an inner set, close to the medial imprints, that are oriented slightly oblique to the trackway axis, and an outer set oriented closer to perpendicular to the trackway axis (Walter, 1985), quite unlike SGDS 1290. Getty (2020) noted similarities between Warvichnium and subaqueous Bifurculapes.

Among described arthropod repichnia, SGDS 1290 architecturally most closely resembles ichnospecies of Siskemia by possessing discreet, compact (not linear) tracks and track sets flanking paired paramedial impressions. Three ichnospecies of Siskemia are presently recognized (Walker, 1985):

- S. bipediculus (Fig. 4KK) comprises small, circular tracks in closely appressed pairs (occasionally trios) in rows oriented perpendicular or slightly oblique to the trackway axis; the pairs are spaced apart at approximately regular intervals and evenly distant from the uniformly straight and narrow paramedial impressions (Walker, 1985). The paramedial impressions lie close to the midline axis, well away from their adjacent tracks (the average ratio of the distance between a paramedial impression and its flanking track to the distance between the medial edges of the paramedial impressions is 1.34; see Supplemental Material).

- S. elegans (Fig. 4LL) has similarly shaped tracks in sets of up to four tracks; the sets similarly lie well away from the likewise straight, narrow, and closely appressed paramedial impressions (the average ratio of the distance between a paramedial impression and its flanking track to the distance between the medial edges of the paramedial impressions is 1.75; see Supplemental Material). S. bipediculus and S. elegans differ primarily in the orientations of their track rows to the trackway axis and the continuities and thicknesses of their paramedial impressions (Walker, 1985), though these could be behavioral and/or substrate-driven variants.

- Siskemia latavia (Fig. 4MM; called "lata-via" by Smith [1909] and Walker [1985], but the ICZN does not permit hyphens in genus or species names) tracks comprise tapered or ovoid tracks arranged in roughly triangular sets of three. Most individual tracks have their 
491

492

493

494

495

496

497

498

499

500

501

502

503

504

505

506

507

508

509

510

511

512

513

514

515

516

517

518

519

520

521

522

523

524

525

526

527

528

529

530

long axes oriented oblique to the trackway axis; track sets have varying orientations to the trackway axis. Tracks in individual $S$. latavia sets usually are spaced well apart from each other; rarely do two individual tracks in a set contact one another. S. latavia tracks lack the regular spacing and arrangements of those of S. elegans and S. bipediculus, and occasional individual tracks lie close to the paramedial impressions, farther medially than in either of the other two Siskemia ichnospecies (the average ratio of the distance between a paramedial impression and its flanking track to the distance between the medial edges of the paramedial impressions is 0.80; see Supplemental Material). Each paramedial impression of S. latavia is slightly wider than those of the other two Siskemia ichnospecies (probably a function of the larger overall size of specimens attributed to this ichnospecies), but retain the close appression to the trackway midline and the uniform straightness.

The tracks of SGDS 1290 vary more in morphology than those of any known Siskemia ichnospecies, but grossly share their layout. Tracks in all three Siskemia ichnospecies have a staggered distribution, similar to, but less pronounced than, that of SGDS 1290. SGDS 1290 differs most markedly from any of the three Siskemia ichnospecies in the morphology and positions of the paramedial impressions: in SGDS 1290, the impressions vary in thickness along their lengths and undulate, in contrast to the thin, straight impressions of all three Siskemia ichnospecies. Additionally, the impressions in SGDS 1290 lie farther apart than those of the three Siskemia ichnospecies. In fact, all of the ichnospecies of Siskemia erected by Smith (1909), as well as both specimens later attributed to this ichnogenus (e.g., Getty et al., 2013; McNamara, 2014; Pollard, Steel \& Undersrud, 1982) and Siskemia-like traces made by extant, archaeognathan insects (Getty et al., 2013), have such thin, linear, closely appressed paramedial impressions (sometimes offset toward one side of the trackway). The only time when archaeognathan traces approach the paramedial impression spacing of SGDS 1290 is when both abdominal styli (laterally) and gonostyli (medially) of the trace makers register impressions and imprints in wet mud, producing two sets of paramedial traces (Getty et al., 2013: fig. 6K, L), but even then the linear, lateralmost paramedial impressions still do not resemble the thick, undulating impressions of SGDS 1290. Simultaneously, in such wet mud, archaeognathan tracks are elongate and oriented oblique to the trackway axis, unlike those in SGDS 1290. In total, SGDS 1290 does not fit neatly into any known Siskemia ichnospecies and does not seem to be an archaeognathan insect trace.

Among traces made by extant arthropods, SGDS 1290 bears similarities to traces made by both notostracans and crayfish. Interpretive drawings of experimental traces made by notostracans figured by Trusheim (1931) depict elongate, crescentic, or tapered tracks oriented perpendicular to paramedial impressions; the tracks are arranged oppositely, unlike those of SGDS 1290. Additionally, the thin, linear paramedial impressions figured by Trusheim (1931) lie so far from the trackway axis that they often contact their accompanying tracks, a phenomenon that only occurs in SGDS 1290 near L4 and R4, where the lateral margins of its undulating paramedial impressions meander particularly far laterally. Tasch (1969) noted, 
531 though, that the drawings presented by Trusheim (1931) were misleading compared to his own 532 experimentally generated notostracan traces. However, he described the morphologies of his 533 notostracan tracks only as "minute en echelon stripes" (Tasch, 1969: 327), which does not 534 adequately specify how they differed from those of Trusheim (1931); track details are impossible 535 to discern in his lone photographic figure (Tasch, 1969: pl. 1.2). Gand et al. (2008) also 536 conducted neoichnological experiments with notostracans, recovering locomotory traces that 537 were less orderly than those illustrated by Trusheim (1931) (Gand et al., 2008: figs. 16.1, 16.2, 538 17.1). Their extant notostracan tracks comprised multiple tracks with rather chaotic distributions 539 lateral to their paramedial impressions, unlike the regular distribution seen in SGDS 1290. Gand 540 et al. (2008) found their notostracan traces to fall within the "etho-morphotype" of Acripes, as 541 exemplified by their novel ichnospecies A. multiformis from the Permian of France. (Linck 542 [1943] and Pollard [1985] also referred Acripes [Merostomichnites of Linck, 1943] tracks to notostracans, but not based on neoichnological experiments.) A. multiformis traces, unlike classic Acripes (Matthew, 1910), possess paramedial imprints, albeit inconsistently. Hammersburg, Hasiotis \& Robison (2018), Häntzschel (1975), Miller (1996), and Pemberton, MacEachern \& Gingras (2007) all supported classic Acripes as a junior synonym of Diplichnites; the issue of synonymy is beyond the scope of this paper, but we note at least that the tracks in fossils that Gand et al. (2008) called A. multiformis differ from SGDS 1290 in the same ways that Diplichnites tracks do (see above). Lastly, Knecht et al. (2009: figs. 5, 6) also illustrated traces made by extant notostracans (Fig. 4NN), which are "tidier" than those of Gand et al. (2008) and resemble those of classic Acripes and Diplichnites, albeit with discontinuous paramedial and curvilinear lateral (external) imprints. The tracks in these traces comprise irregular, ellipsoidal sets oriented oblique to the trackway axis, unlike those of SGDS 1290. In total, SGDS 1290 is unlikely to be a notostracan trace.

Fairchild \& Hasiotis (2011) conducted neoichnological experiments with crayfish to examine their locomotory traces. These traces varied in morphology depending on substrate conditions (sediment grain size and saturation) and slope; in general, when clearest, they consist of sets of 1-4 circular, tapering, ellipsoidal, or elongate tracks, occasionally of different sizes, that are oriented parallel to the trackway axis and that lie lateral to a pair of undulating, variably thick paramedial impressions that lie closer to their flanking tracks than to each other (Figs. 3D, 4OO). Morphologically, the tracks and impressions match those of SGDS 1290, although the tracks made by extant crayfish often are larger than those of SGDS 1290 when produced in dry substrate (Fairchild \& Hasiotis, 2011: fig. 9). Track sets in extant crayfish traces have complex arrangements: when comprised of multiple traces, they frequently are in rows oriented perpendicular to the trackway axis, but sometimes rows are oblique to the trackway axis. When fewer tracks are preserved, sets can appear to lie in single, parallel rows on either side of the paramedial impressions. Track positions can be opposite to staggered to alternating, also as in SGDS 1290. In both track and paramedial impression morphology, as well as in overall trace architecture, SGDS 1290 strongly resembles crayfish traces made in damp silt and clay (Fairchild \& Hasiotis, 2011: fig. 2e, f), dry and saturated, very fine-grained sand (Fig. 3D; 
571 Fairchild \& Hasiotis, 2011: fig. 4a, b, e, f), dry and damp, fine-grained sand (Fairchild \& 572 Hasiotis, 2011: fig. 5a-d), and saturated medium sand (Fairchild \& Hasiotis, 2011: fig. 6e, f).

573 SGDS 1290 is preserved in, and was presumably registered in, a fine-grained sandstone,

574 lithologically matching one set of experimental conditions in Fairchild \& Hasiotis (2011).

575 However, SGDS 1290 is not as detailed as many of the experimentally generated crayfish traces

576 in comparable sediments. This could indicate one or more things: the fossil could be a slight

577 overtrack (sensu Bertling et al., 2006) rather than a direct natural cast; the trace maker may have

578 been partly buoyant; and/or trace-maker behavior and sediment consistency combined such that

579 the lighter limbs did not impress as deeply as the heavier tail.

580

\section{Discussion}

\section{Trace maker}

The stronger resemblance of SGDS 1290 to experimental crayfish locomotion traces than to any known ichnotaxon, or other documented extant arthropod trace, implies a crayfish or crayfish-like maker for the fossil. Whether SGDS 1290 had a crayfish-like or an actual crayfish maker depends on whether the term "crayfish" is used to refer to members of a monophyletic clade (Parastacidae $+($ Astacidae $+($ Cambaridae + Cricoidoscelosidae $))$; Karasawa, Schweitzer \& Feldmann, 2013) of freshwater (and brackish water if Protastacus is included, sensu Karasawa, Schweitzer \& Feldmann [2013]) lobsters, or, more broadly, to any freshwater, lobsterlike crustacean regardless of phylogenetic position, which presumes that more than one crayfishlike lineage colonized terrestrial environments in the past. Here we use the term in the monophyletic sense: true crayfish comprise Astacida (sensu Karasawa, Schweitzer \& Feldmann, 2013; Schram \& Dixon, 2004; Shen, Braband \& Scholtz, 2015). Whether or not the maker of SGDS 1290 was a true crayfish is unclear: the oldest undisputed crayfish body fossils are from the Early Cretaceous (Garassino, 1997; Martin et al., 2008; Shen, 2003; Taylor, Schram \& Shen, 1999), although unnamed, Late Jurassic specimens from western Colorado also have been called crayfish (Hasiotis, Kirkland \& Callison, 1998). Despite this, a Triassic or earlier origin for true crayfish has been hypothesized frequently (Breinholt, Pérez-Losada \& Crandall, 2009; Crandall \& Buhay, 2008; Porter, Pérez-Losada \& Crandall, 2005; Schram, 2001; Schram \& Dixon, 2004; Wolfe et al., 2019) and possibly substantiated by fossil burrows referred to crayfish from the Early Permian (Hembree \& Swaninger, 2018) and Late Permian-Early Triassic (Baucon et al., 2014; Hasiotis \& Mitchell, 1993).

Several Late Triassic body-fossil specimens also have been reported as crayfish (Hasiotis,

605 Kirkland, 2010), but the identities of these specimens as true astacidans has not been established. 606 Miller \& Ash (1988) placed a Late Triassic specimen from Petrified Forest National Park, 607 Arizona in Enoploclytia, which is an erymid lobster, not an astacidan, genus. That generic 608 placement subsequently has been contested (Amati, Feldmann \& Zonneveld, 2004; Schweitzer et 609 al., 2010; Urreta, 1989), so the specimen needs detailed restudy, but if it pertains to Erymidae 610 rather than Astacida, then it indicates that a lineage of erymid lobsters colonized terrestrial 
611 environments, possibly before true (monophyletic) crayfish. Some older analyses (reviewed in

612 Rode \& Babcock, 2003) postulated crayfish origins within Erymidae, but more recent

613 phylogenetic analyses (Devillez, Charbonnier \& Barreil, 2019; Karasawa, Schweitzer \&

614 Feldmann, 2013; Rode \& Babcock, 2003; Schram \& Dixon, 2004; Stern \& Crandall, 2015) have

615 recovered (a frequently paraphyletic) Erymidae with members at varying distances from

616 Astacida. If those hypothesized phylogenetic relationships are correct, then no erymid can, in a

617 monophyletic sense, be considered a crayfish, even if it was a freshwater taxon. But regardless of

618 semantics or phylogenetic relationships, crayfish and erymid morphological similarities suggest

619 that their locomotory traces might be indistinguishable, making a definitive attribution of SGDS

6201290 impossible.

621 A crayfish or crayfish-like trace maker for SGDS 1290 is tenable both chronologically

622 and ecologically. As mentioned above, multiple crayfish-like morphotypes have been found in

623 the Upper Triassic Chinle Formation of Arizona and Utah (Hasiotis, 1995; Miller \& Ash, 1988;

624 Santucci \& Kirkland, 2010). The Moenave Formation overlies the Chinle Formation in

625 southwestern Utah, so crayfish or crayfish-like decapods plausibly could have been present in

626 and around freshwater Lake Whitmore both geographically and stratigraphically. As-yet-

627 undescribed, crayfish or crayfish-like body fossils also have been recovered from lacustrine

628 sediments of the uppermost Triassic Chatham Group (Newark Supergroup) in North Carolina

629 (Olsen \& Huber, 1997), attesting to how widespread such arthropods were in terrestrial

630 environments in North America even prior to the Jurassic.

631

632

633

634

635

636

637

638

639

640

641

642

643

644

645

646

647

648

649

650

\section{Ichnotaxonomy}

To date, no fossil arthropod locomotory ichnotaxon has been attributed definitively to a crayfish or crayfish-like trace maker. Several such ichnotaxa have been attributed, for various reasons, to crustaceans (e.g., Braddy, 2003; Gand et al., 2008; Lima, Minter \& Netto, 2017; Pirrie, Feldmann \& Buatois, 2004; Savage, 1971; Walker, Holland \& Gardiner, 2003); additionally, some purported crustacean tracks have not been assigned to particular ichnotaxa (e.g., Imaizumi, 1967; Karasawa, Okamura \& Naruse, 1990; Matsuoka et al., 1993), including mortichnial trackways leading to Eryma, Eryon, and Mecochirus lobster body fossils from the marine, Upper Jurassic lithographic limestones of Germany (Glaessner, 1969: fig. 243A; Seilacher, 2008: fig. 2; Viohl, 1998: fig. 6). None of these German taxa are crayfish, though morphological similarities of Eryma and Mecochirus to crayfish might mean that they would have produced indistinguishable locomotory ichnofossils during normal, forward locomotion. None of their traces have been granted detailed description or ichnotaxonomic assignment.

Only three locomotory ichnotaxa have been attributed specifically to crayfish. First, Heidtke (1990) erected Pollichianum repichnum for Early Permian ichnofossils from Germany that he attributed to the "crawfish" (in the English abstract; "Krebses" in the German abstract) Uronectes fimbriatus, also from the Early Permian of Germany. However, Uronectes has long been recognized as a syncarid (Brooks, 1962; Calman, 1934; Perrier et al., 2006), not an astacidan, or even a decapod, so the term appearing in the English abstract likely is a simple 
651 translation error. Furthermore, however, P. repichnum is not differentiable from the resting trace 652 (cubichnion) P. cubichnum (O'Brien, Braddy \& Radley, 2009) and therefore is a junior synonym 653 and is not a locomotory trace. In any case, Pollichianum is morphologically quite unlike both 654 SGDS 1290 and experimentally generated crayfish traces (Fairchild \& Hasiotis, 2011). Second, 655 Bolliger \& Gubler (1997) hypothesized that their novel, early Miocene ichnospecies Hamipes 656 molassicus was made by a buoyed (presumably swimming) crayfish. Getty (2018) referred these 657 specimens to Conopsoides; later, Getty \& Burnett (2019) suggested that at least some of the 658 specimens may pertain to Acanthichnus, and they differ from SGDS 1290 for the same reasons 659 outlined above for Acanthichnus. Third, de Gibert et al. (2000) attributed Early Cretaceous, 660 Spanish specimens that they assigned to Hamipes didactylus to crayfish. Getty (2018) attributed 661 these tracks to Bifurculapes and maintained a crustacean track maker for H. didactylus, but was not more specific. However, neither Bifurculapes nor Hamipes resemble experimentally generated crayfish traces (Fairchild \& Hasiotis, 2011), or any of the mortichnial decapod traces, and thus are unlikely to have been made by a crayfish-like decapod, at least while walking. Lastly, we also note that unnamed trackways attributed to crayfish from the Upper Triassic 666 Chinle Formation of Utah were mentioned, but not described, by Hasiotis (1991); Fairchild \& Hasiotis (2011) did not note whether or not these were similar to their experimentally generated traces. Additionally, an unnamed "crayfish locomotion trace" was figured, but not described, by Rainforth \& Lockley (1996: fig. 1b); it does not resemble either SGDS 1290 or experimentally generated crayfish traces (Fairchild \& Hasiotis, 2011).

As detailed above, SGDS 1290 does not fit neatly into any existing ichnospecies of Siskemia. Whether or not to place it in a novel ichnospecies, or even ichnogenus, is, therefore, an open question. Bertling et al. (2006), Gaillard (2011b), and Minter, Braddy \& Davis (2007) provided solid criteria for the erection of new ichnotaxa, the latter particularly for arthropods. One criterion is that a new ichnotaxon ideally should be represented by a substantial number of specimens that demonstrate behavioral and substrate-based morphological variation; this prevents erecting several ichnotaxa for minor, readily explained variations in trace morphology. SGDS 1290, as a singular specimen, certainly does not meet that criterion, but Minter, Braddy \& Davis (2007) also allowed that truly unique morphologies exhibited by singular specimens can support an ichnotaxon. In terms of uniqueness, another criterion is whether or not a new morphotype falls onto a continuum, established or hypothetical, of morphologies within an established ichnotaxon. SGDS 1290 is closest morphologically to ichnospecies of Siskemia, but has several distinctions from any established ichnospecies therein, particularly the thick and undulating paramedial impressions and the wider spacing between the paramedial impressions and consequent closer appression of the paramedial impressions to the tracks: the average ratios of the distance between a paramedial impression and its flanking track to the distance between the medial edges of the paramedial impressions are 1.34 for S. bipediculus, 1.75 for S. elegans, and 0.80 for S. latavia compared to 0.31 for SGDS 1290 (see Supplemental Material). No 690 published specimen of Siskemia demonstrates the features of SGDS 1290; nor do Siskemia-like traces made by archaeognathan insects in experimental conditions (Getty et al., 2013). Thus, 
691 SGDS 1290 does not appear to fall within the established Siskemia continuum. The greater 692 prominence (depth) of the paramedial impressions of SGDS 1290 than their associated tracks 693 suggests either a trace maker with heavier tail elements than the gonostyli of an archaeognathan 694 insect or an archaeognathan trace maker with unusually large styli adopting an unusual posture 695 (possibly partly buoyant), flexing its caudal region downward to create deep styli impressions 696 but not deep track impressions. We consider the latter unlikely; thus, SGDS 1290 does not 697 appear to fall within a hypothetical Siskemia continuum, either. However, SGDS 1290 falls 698 within the continuum of trace morphologies made by extant crayfish in experimental conditions 699 (Fairchild \& Hasiotis, 2011). No philosophical basis has been established for the recognition of

700

701

702

703

704

705

706

707

708

709

710

711

712

713

714

715

716

717

718

719

720

721

722

723

724

725

726

727

728

729

730 novel ichnotaxa on the basis of comparison with traces made by extant organisms; only by comparison with fossil ichnotaxa because extant traces cannot be the basis for an ichnotaxon (Bertling et al., 2006; International Commission on Zoological Nomenclature, 1999).

SGDS 1290 clearly is morphologically distinctive. Lacking a sufficient number of specimens with which to determine ranges of morphological variation, however, erecting a new ichnogenus for it clearly is unwarranted. Yet we feel that its unique morphology warrants ichnotaxonomic distinction. Given its distant similarity to Siskemia ichnospecies, we therefore herein place it in a new ichnospecies of that ichnogenus.

\section{Systematic Ichnology}

Ichnofamily Protichnidae Uchman, Gaździcki \& Błażejowski 2018

\section{Ichnogenus Siskemia Smith 1909}

\section{Type Ichnospecies Siskemia elegans Smith 1909}

Diagnosis. Trace consisting of parallel rows of grouped tracks on either side of two parallel, paramedial impressions. Each group of tracks consists of up to four imprints arranged in series, transversely or obliquely to the midline of the trackway (following Walker, 1985). Walker (1985) further specified that Siskemia was diagnosed by paramedial impressions with maximum widths of $0.5 \mathrm{~mm}$, but following Bertling et al. (2006), size is not a suitable ichnotaxobase.

Ichnospecies Siskemia eurypyge isp. nov.

Figure 3A, B

Diagnosis. Two parallel, undulating, paramedial impressions flanked externally by closely appressed sets of 1-3 small, ovoid to tapered to elongate tracks; tapered and elongate tracks have long axes parallel or oblique to the trackway axis. Track sets are oriented perpendicular to the trackway axis. Left and right tracks are arranged in a staggered to alternating pattern. Paramedial impressions are mediolaterally thick, but discontinuous, tapering out of existence briefly in some places. Impressions are gently undulating (low amplitude). The paramedial impressions lie far 
731 from the trackway axis, generally closer to (and sometimes in contact with) the tracks than to the 732 midline axis or each other.

733 Holotype. Natural cast specimen SGDS 1290, St. George Dinosaur Discovery Site, St. George, 734 Utah, USA.

735 Type locality. "Bug Crossing Quarry," SGDS Loc. 87, St. George Dinosaur Discovery Site, St. 736 George, Washington County, Utah, USA (Fig. 1).

737 Stratigraphy. "Top Surface” of Johnson Farm Sandstone Bed (unit 40 of Kirkland et al., 2014),

738 Whitmore Point Member, Moenave Formation (Fig. 2). Hettangian, Lower Jurassic.

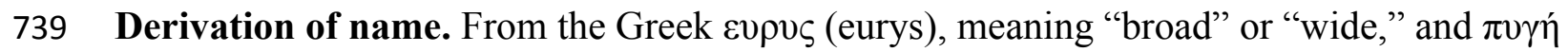

740 (pyge), meaning "rump." The ichnospecies name refers to the wider spacing between the

741 paramedial impressions, made by the rear end of the trace maker, than those of other Siskemia

742 ichnospecies.

743

744

745

746

747

748

749

750

751

752

753

754

755

756

757

758

759

760

761

762

763

764

765

766

767

768

769

770

\section{Conclusions}

SGDS 1290, from the Lower Jurassic (Hettangian) Whitmore Point Member of the Moenave Formation, consists of two paramedial impressions that are flanked by staggered to alternating sets of tapered or elongate tracks. The traces closely resemble those made by extant crayfish (Fairchild \& Hasiotis, 2011) and are similar in components to traces placed in the ichnogenus Siskemia (Smith 1909; Walker, 1985). In previously recognized Siskemia ichnospecies, the paramedial impressions are thin, relatively straight, and closely appressed to the trackway axis. But in SGDS 1290, paramedial impressions have the opposite morphology and arrangement: they are thick and lie closer to their tracks than the medial axis of the trackway. SGDS 1290 paramedial impressions also undulate, which is not seen in any previously known Siskemia ichnospecies. Thus, we erect a new ichnospecies, Siskemia eurypyge, to house SGDS 1290 and as-yet undiscovered traces with this morphology and arrangement.

Placing SGDS 1290 in Siskemia extends the known range of the ichnogenus into the Early Mesozoic. All other reported occurrences of the ichnogenus are Paleozoic in age: Early Silurian (McNamara, 2014; Trewin \& McNamara, 1994), Late Silurian (Davies, Sansom \& Turner, 2006), Early Devonian (Pollard, Steel \& Undersrud, 1982; Pollard \& Walker, 1984; Smith, 1909; Walker, 1985), and Pennsylvanian (Getty et al., 2013). However, age should not be a factor in ichnotaxonomy (Bertling et al., 2006). At least some Paleozoic Siskemia traces likely were made by archaeognathan insects (Getty et al., 2013), which are extant and for which body fossils are known as early as the Devonian. Based on their similarity to traces made by extant crayfish (Fairchild and Hasiotis, 2011), S. eurypyge likely was made by a crayfish or crayfishlike crustacean, for which body fossils are known as early as the Late Triassic and which also are extant. Thus, Siskemia ispp. traces would be expected to occur from Early Silurian to Recent, but thus far have not been documented except for the occurrences noted above.

SGDS 1290 expands the ichnological record of crayfish and crayfish-like animals to include repichnia in addition to domichnia. Fossil burrows (Camborygma ispp.), usually attributed to crayfish, are well known at some sites and in some formations (e.g., Hasiotis, 1995; 
771

772

773

774

775

776

777

778

779

780

781

782

783

784

785

786

787

788

789

790

791

792

793

794

795

796

797

798

799

800

801

802

803

804

805

806

807

808

809

Hasiotis \& Bown, 1996; Hasiotis \& Honey, 1995; Hasiotis \& Mitchell, 1993; Hasiotis, Kirkland \& Callison, 1998; see Schram \& Dixon [2004] concerning pre-Cretaceous examples), attesting to the presences — and, in some places, abundances — of crayfish and/or crayfish-like taxa in Mesozoic-Cenozoic freshwater paleoecosystems. Yet locomotion traces made by these burrowers oddly have never before been documented as ichnofossils, possibly because they infrequently venture far from their burrows in substrates suitable for registering locomotory traces, as with modern crayfish (Martin, 2013). SGDS 1290 is the first documented locomotory ichnofossil made by a freshwater crayfish or crayfish-like organism, as well as the first fossil evidence of such a taxon in the Lower Jurassic Moenave Formation and indeed the Early Jurassic of the southwestern US. The absence of Camborygma burrows in the Moenave Formation that would have been made by the SGDS 1290 trace maker is puzzling, and may be a consequence of a lack of recognition; alternatively, the producer of SGDS 1290 was not a burrower.

\section{Acknowledgments}

We thank Patrick R. Getty (Collin College) for invaluable discussion and for loaning us peels of Siskemia traces from Scotland. Dianne Aldrich (Dixie State University library) displayed uncanny skill in obtaining copies of often obscure papers via InterLibrary Loan. Kathleen Huber (SEPM) granted permission to reproduce the photo in Fig. 3D from Fairchild \& Hasiotis (2011). We thank SGDS volunteer, Jon Cross, for discovering and collecting the specimen. We also thank Patrick Getty, Carlos Neto de Carvalho, and an anonymous reviewer for their time and very helpful comments, which greatly improved the paper.

\section{References Cited}

Aceñolaza FG. 1978. Trazas fosiles de la Formación Patquía en el Bordo Atravesado, Sierra de Famatina, La Rioja. Acta Geológica Lilloana 15:19-29.

Aceñolaza FG, Buatois LA. 1991. Trazas fosiles del Paleozoico superior continental argentino. Ameghiniana 28:89-108.

Aceñolaza FG, Buatois LA. 1993. Nonmarine perigondwanic trace fossils from the Late Paleozoic of Argentina. Ichnos 2:183-201. DOI: 10.1080/10420949309380092.

Amati L, Feldmann RM, Zonneveld J-P. 2004. A new family of Triassic lobsters (Decapoda: Astacidea) from British Columbia and its phylogenetic context. Journal of Paleontology 78:150-168. DOI: 10.1666/0022-3360(2004)078<0150:ANFOTL>2.0.CO;2.

Anderson AM. 1975a. Turbidites and arthropod trackways in the Dwyka glacial deposits (Early Permian) of southern Africa. Transactions of the Geological Society of South Africa 78:265-273.

Anderson AM. 1975b. The "trilobite" trackways in the Table Mountain Group (Ordovician) of South Africa. Palaeontologia Africana 18:35-45.

Anderson AM. 1981. The Umfolozia arthropod trackways in the Permian Dwyka and Ecca series of South Africa. Journal of Paleontology 55:84-108. 
810

811

812

813

814

815

816

817

818

819

820

821

822

823

824

825

826

827

828

829

830

831

832

833

834

835

836

837

838

839

840

841

842

843

844

845

846

847

848

849

Archer AW, Maples CG. 1984. Trace-fossil distribution across a marine-to-nonmarine gradient in the Pennsylvanian of southwestern Indiana. Journal of Paleontology 58:448-466.

Baucon A, Ronchi A, Felletti F, de Carvalho CN. 2014. Evolution of crustaceans at the edge of the end-Permian crisis: ichnonetwork analysis of the fluvial succession of Nurra (Permian-Triassic, Sardinia, Italy). Palaeogeography, Palaeoclimatology, Palaeoecology 410:74-103. DOI: 10.1016/j.palaeo.2014.05.034.

Bertling M, Braddy SJ, Bromley RG, Demathieu GR, Genise J, Mikuláš R, Nielsen JK, Nielsen KSS, Rindsberg AK, Schlirf M, Uchman, A. 2006. Names for trace fossils: a uniform approach. Lethaia 39:265-286. DOI: 10.1080/00241160600787890.

Bolliger, T, Gubler, T. 1997. Arthropodenlaufspuren von Hochdorf (LU) und weitere Arthropodennachweise aus der Oberen Süsswassermolasse der Schweiz. Eclogae Geologicae Helvetiae 90:617-627.

Braddy SJ. 1995. The ichnotaxonomy of the invertebrate trackways of the Coconino Sandstone (Lower Permian), northern Arizona. In: Lucas SG, Heckert AB, eds. Early Permian Footprints and Facies. New Mexico Museum of Natural History and Science Bulletin 6: 219-224.

Braddy SJ. 2003. Trackways - arthropod locomotion. In: Briggs DEG, Crowther PR, eds. Palaeobiology II. Malden: Blackwell Publishing, 389-393.

Braddy SJ, Almond JE. 1999. Eurypterid trackways from the Table Mountain Group (Ordovician) of South Africa. Journal of African Earth Sciences 29:165-177. DOI: 10.1016/S0899-5362(99)00087-1.

Braddy SJ, Milner ARC. 1998. A large arthropod trackway from the Gaspé Sandstone Group (Middle Devonian) of eastern Canada. Canadian Journal of Earth Science 35:11161122. DOI: $10.1139 /$ cjes-35-10-1116.

Brady LF. 1947. Invertebrate tracks from the Coconino Sandstone of northern Arizona. Journal of Paleontology 21:466-472.

Brady LF. 1949. Oniscoidichnus, new name for Isopodichnus Brady 1947 not Bornemann 1889. Journal of Paleontology 23:573.

Breinholt J, Pérez-Losada M, Crandall KA. 2009. The timing and diversification of freshwater crayfishes. In: Martin JW, Crandall KA, Felder DJ, eds. Decapod Crustacean Phylogenetics. Boca Raton: CRC Press, 343-356.

Briggs DEG, Rolfe WDI, Brannan J. 1979. A giant myriapod trail from the Namurian of Arran, Scotland. Palaeontology 22:273-291.

Brooks HK. 1962. On the fossil Anaspidacea, with a revision of the classification of the Syncarida. Crustaceana 4:229-242.

Buatois LA, Mángano MG. 2003. Caracterización ichnológica y paleoambiental de la localidad tipo de Orchesteropus atavus Frenguelli, Huerta de Huachi, Provincia de San Juan, Argentina. Ameghiniana 40:53-70.

Buatois LA, Mángano MG. 2004. Animal-substrate interactions in freshwater environments: applications of ichnology in facies and sequence stratigraphic analysis of fluvio- 
850

851

852

853

854

855

856

857

858

859

860

861

862

863

864

865

866

867

868

869

870

871

872

873

874

875

876

877

878

879

880

881

882

883

884

885

886

887

888

889

lacustrine successions. In: McIlroy D, ed. The Application of Ichnology to Palaeoenvironmental and Stratigraphic Analysis. Geological Society of London Special Publication 228:311-333.

Buatois LA, Mángano MG, Maples CG, Lanier WP. 1998. Ichnology of an Upper Carboniferous fluvio-estuarine paleovalley: the Tonganoxie Sandstone, Buildex Quarry, eastern Kansas, USA. Journal of Paleontology 72:152-180. DOI: 10.1017/S0022336000024094.

Burton-Kelly ME, Erickson JM. 2010. A new occurrence of Protichnites Owen, 1852, in the Late Cambrian Potsdam Sandstone of the St. Lawrence Lowlands. Open Paleontology Journal 3:1-13. DOI: 10.2174/1874425701003010001.

Calman WT. 1934. Notes on Uronectes fimbriatus (Jordan), a fossil crustacean of the division Syncarida. Annals and Magazine of Natural History, $10^{\text {th }}$ Series 75:321-330.

Caster KE. 1938. A restudy of the tracks of Paramphibius. Journal of Paleontology 12:3-60.

Caster KE. 1944. Limuloid trails from the Upper Triassic (Chinle) of the Petrified National Forest National Monument, Arizona. American Journal of Science 242:74-84. DOI: 10.2475/ajs.242.2.

Chapman F. 1929. On some remarkable annelid remains from Arthur River, N.W. Tasmania. Papers and Proceedings of the Royal Society of Tasmania 1928:1-5.

Charbonnier S, Vannier J, Hantzpergue P, Gaillard C. 2010. Ecological significance of the arthropod fauna from the Jurassic (Callovian) La Voulte Lagerstätte. Acta Palaeontologica Polonica 55:111-132. DOI: 10.4202/app.2009.0036.

Chen Z, Chen X, Zhou C, Yuan X, Xiao, S. 2018. Late Ediacaran trackways produced by bilaterian animals with paired appendages. Science Advances 4:eaao669. DOI: 10.1126/sciadv.aao6691.

Collette JH, Gass KC, Hagadorn JW. 2012. Protichnites eremita unshelled? Experimental model-based neoichnology and new evidence for a euthycarcinoid affinity for this ichnospecies. Journal of Paleontology 86:442-454. DOI: 10.1666/11-056.1.

Collette JH, Hagadorn JW, Lacelle MA. 2010. Dead in their tracks - Cambrian arthropods and their traces from intertidal sandstones of Quebec and Wisconsin. Palaios 25:475-486. DOI: 10.2110/palo.2009.p09-134r.

Crandall KA, Buhay JE. 2008. Global diversity of crayfish (Astacidae, Cambaridae, and Parastacidae-Decapoda) in freshwater. Hydrobiologia 595:295-301. DOI: 10.1007/s10750-007-9120-3.

Curran HA, Savarese M, Glumac B. 2016. The stellate burrow: a large and complex trace fossil in Holocene carbonate eolianites of the Bahamas. Ichnos 23:126-137. DOI: 10.1080/10420940.2015.1132212.

Dalman SG, Lucas SG. 2015. Lower Jurassic arthropod resting trace from the Hartford Basin of Massachusetts, USA. Ichnos 22:177-182. DOI: 10.1080/10420940.2015.1059337.

Davies NS, Sansom IJ, Turner P. 2006. Trace fossils and paleoenvironments of a Late Silurian marginal-marine/alluvial system: the Ringerike Group (Lower Old Red Sandstone), Oslo region, Norway. Palaios 21:46-62. DOI: 10.2110/palo.2003.p03-08. 
890

891

892

893

894

895

896

897

898

899

900

901

902

903

904

905

906

907

908

909

910

911

912

913

914

915

916

917

918

919

920

921

922

923

924

925

926

927

928

929

Davis RB, Minter NJ, Braddy SJ. 2007. The neoichnology of terrestrial arthropods. Palaeogeography, Palaeoclimatology, Palaeoecology 255:284-307. DOI: 10.1016/j.palaeo.2007.07.013.

Dawson JW. 1873. Impressions and footprints of aquatic animals and imitative markings, on Carboniferous rocks. American Journal of Science 105:16-24. DOI: 10.2475/ajs.s35.25.16.

de Carvalho CN, Pereira B, Klompmaker A, Baucon A, Moita JA, Pereira P, Machado S, Belo J, Carvalho J, Mergulhão L. 2016. Running crabs, walking crinoids, grazing gastropods: behavioral diversity and evolutionary implications of the Cabeço da Ladeira Lagerstätte (Middle Jurassic, Portugal). Comunicações Geológicas 103 (especial I):39-54.

de Gibert JM, Fregenal-Martínez MA, Buatois LA, Mángano MG. 2000. Trace fossils and their palaeoecological significance in Lower Cretaceous lacustrine conservation deposits, El Montsec, Spain. Palaeogeography, Palaeoclimatology, Palaeoecology 156:89-101. DOI: 10.1016/S0031-0182(99)00133-9.

Devillez J, Charbonnier S, Barreil, V. 2019. An attempt to clarify phylogenetic affinities of erymid lobsters (Decapoda) using morphological characters. Arthropod Systematics and Phylogeny 77:365-395. DOI: 10.26049/ASP77-3-2019-1.

Donohoo-Hurley LL, Geissman JW, Lucas SG. 2010. Magnetostratigraphy of the uppermost Triassic and lowermost Jurassic Moenave Formation, western United States: correlation with strata in the United Kingdom, Morocco, Turkey, Italy, and eastern United States. Geological Society of America Bulletin 122:2005-2019. DOI: 10.1130/B30136.1.

Eiseman C, Charney N. 2010. Tracks \& Sign of Insects and Other Invertebrates: a Guide to North American Species. Mechanicsburg, PA: Stackpole Books.

Ekdale AA, Bromley RG, Loope DB. 2007. Ichnofacies of an ancient erg: a climatically influenced trace fossil association in the Jurassic Navajo sandstone, southern Utah, USA. In: Miller III W, ed. Trace Fossils: Concepts, Problems, Prospects. Amsterdam: Elsevier, 562-574.

Fairchild JM, Hasiotis ST. 2011. Terrestrial and aquatic neoichnological laboratory experiments with the freshwater crayfish Orconectes: trackways on media of varying grain size, moisture, and inclination. Palaios 26:790-804. DOI: 10.2110/palo.2011.p11-066r.

Fillmore DL, Lucas SG, Simpson EL. 2012. Ichnology of the Mississippian Mauch Chunk Formation, eastern Pennsylvania. New Mexico Museum of Natural History and Science Bulletin 54:1-136.

Fillmore DL, Szajna MA, Lucas SG, Hartline BW, Simpson EL. 2017. Ichnology of a Late Triassic lake margin: the Lockatong Formation, Newark Basin, Pennsylvania. New Mexico Museum of Natural History and Science Bulletin 76:1-107.

Gaillard C. 2011a. A giant limulid trackway (Kouphichnium lithographicum) from the lithographic limestones of Cerin (Late Kimmeridgian, France): ethological and environmental implications. Swiss Journal of Geosciences 104(suppl. 1):57-72. DOI: 10.1007/s00015-010-0032-2.

Peer) reviewing PDF | (2020:09:52634:1:1:NEW 19 Nov 2020) 
930 Gaillard C. 2011b. Ichnotaxinomie et notion d'ichnoespèce. Comptes Rendus Palevol 10:209-

931 218. DOI: 10.1016/j.crpv.2010.10.007.

932 Gaillard C, Hantzpergue P, Vannier J, Margerard AL, Mazin JM. 2005. Isopod trackways from

933 the Crayssac Lagerstätte, Upper Jurassic, France. Palaeontology 48:947-962.

934 Gand G, Garric J, Schneider J, Walter H, Lapeyrie J, Martin C, Thiery, A. 2008. Notostraca

935 trackways in Permian playa environments of the Lodève Basin (France). Journal of

$936 \quad$ Iberian Geology 34:73-108.

937 Garassino A. 1997. The macruran decapod crustaceans of the Lower Cretaceous (lower

938 Barremian) of Las Hoyas (Cuenca, Spain). Atti della Società Italiana di Scienze Naturali

939 e del Museo Civico di Storia Naturale di Milano 137:101-126.

940 Genise JF. 2017. Ichnoentomology: Insect Traces in Soils and Paleosols. Switzerland: Springer

941 International Publishing AG. DOI: 10.1007/978-3-319-28210-7.

942 Getty PR. 2016. Bifurculapes Hitchcock 1858: a revision of the ichnogenus. Atlantic Geology

943 52:247-255. DOI: 10.4138/atlgeol.2016.013.

944 Getty PR. 2018. Revision of the Early Jurassic arthropod trackways Camurichnus and Hamipes.

945

946

947

948

949

950

951

952

953

954

955

956

957 Boletín de la Sociedad Geológica Mexicana 70:281-292. DOI: 10.18268/BSGM2018v70n2a1.

Getty PR. 2020. Evidence that the fossil insect trackway Bifurculapes laqueatus Hitchcock, 1858 was made underwater. Acta Geologica Polonica 70:125-133. DOI: 10.24425/agp.2019.126456.

Getty PR, Burnett J. 2019. Conopsoides Hitchcock 1858: an ichnological chimera of Acanthichnus and Bifurculapes. Atlantic Geology 55:389-398. DOI: 10.4138/atlgeol.2019.014.

Getty PR, Sproule R, Wagner DL, Bush AM. 2013. Variation in wingless insect trace fossils: insights from neoichnology and the Pennsylvanian of Massachusetts. Palaios 28:243258. DOI: 10.2110/palo.2012.p12-108r.

Gibbard PL, Stuart AJ. 1974. Trace fossils from proglacial lake sediments. Boreas 3:69-74.

Gilmore CW. 1926. Fossil footprints from the Grand Canyon. Smithsonian Miscellaneous $958 \quad$ Collections 77(9):1-41.

959 Gilmore CW. 1927. Fossil footprints from the Grand Canyon: second contribution. Smithsonian 960 Miscellaneous Collections 80(3):1-78.

961 Glaessner MF. 1957. Paleozoic arthropod trails from Australia. Paläontologische Zeitschrift 962 31:103-109. DOI: 10.1007/BF02988968.

963 Glaessner MF. 1969. Decapoda. In: Moore, RC, ed. Treatise on Invertebrate Paleontology Part 964 R: Arthropoda 4, Vol. 2. Lawrence: University of Kansas Printing Service, 399-566.

965 Good TR, Ekdale AA. 2014. Paleoecology and taphonomy of trace fossils in the eolian Upper 10.2110/palo.2014.013.

969

Guthörl P. 1934. Die Arthropoden aus dem Carbon und Perm des Saar-Nahe-Pfalz-Gebietes. Abhandlungen der Preußischen Geologischen Landesanstalt, Neue Folge 164:1-219. 
970

971

972

973

974

975

976

977

978

979

980

981

982

983

984

985

986

987

988

989

990

991

992

993

994

995

996

997

998

999

1000

1001

1002

1003

1004

1005

1006

1007

1008

1009

Hagadorn JW, Seilacher A. 2009. Hermit arthropods 500 million years ago? Geology 37:295298. DOI: 10.1130/G25181A.1.

Hammersburg SR, Hasiotis ST, Robison RA. 2018. Ichnotaxonomy of the Cambrian Spence Shale Member of the Langston Formation, Wellsville Mountains, northern Utah, USA. Paleontological Contributions 2018(20):1-66. DOI: 10.17161/1808.26428.

Hanken NS, Stormer L. 1975. The trail of a large Silurian eurypterid. Fossils and Strata 4:255270.

Häntzschel W. 1975. Treatise on Invertebrate Paleontology Part W: Miscellanea, Supplement 1: Trace Fossils and Problematica, $2^{\text {nd }}$ Ed. Lawrence: University of Kansas Printing Service.

Hasiotis ST 1991. Paleontology, ichnology, and paleoecology of the Upper Triassic Chinle Formation of the Canyonlands, southeastern Utah. M.A. Thesis, State University of New York at Buffalo.

Hasiotis ST. 1995. Crayfish fossils and burrows from the Upper Triassic Chinle Formation, Canyonlands National Park, Utah. In: Santucci VL, McClelland L, eds. National Park Service Research Volume 2. National Park Service Technical Report NPS/NRPO/NRTR95/16:49-53.

Hasiotis ST, Bown TM. 1996. A short note about crayfish burrows from the Paleocene-Eocene Claron Formation, southwestern Utah, USA. Freshwater Crayfish 11:121-129.

Hasiotis ST, Honey JG. 1995. Crayfish burrows and their paleohydrologic significance in Paleocene continental deposits, Washakie, Great Divide, and Hanna Basins, Wyoming, USA. Freshwater Crayfish 10:105-117.

Hasiotis ST, Kirkland JI, Callison G. 1998. Crayfish fossils and burrows from the Upper Jurassic Morrison Formation of western Colorado. In: Carpenter K, Chure DJ, Kirkland JI, eds. The Upper Jurassic Morrison Formation: An Interdisciplinary Study, Part 2. Modern Geology 22:481-491.

Hasiotis ST, Mitchell CE. 1993. A comparison of crayfish burrow morphologies: Triassic and Holocene fossil, paleo- and neo-ichnological evidence, and the identification of their burrowing signatures. Ichnos 2:291-314. DOI: 10.1080/10420949309380104.

Heidtke U. 1990. Pollichianum cubichnum nov. ichnogen. et ichnospec. und Pollichianum repichnum nov. ichnospec., zwei neue Invertebratenichnia aus dem saar-pfälzischen Rotliegend (Unter-Perm, SW-Deutschland). Mitteilungen der Pollichia 77:133-139.

Hembree DI, Swaninger ES. 2018. Large Camborygma isp. in fluvial deposits of the Lower Permian (Asselian) Dunkard Group, southeastern Ohio, U.S.A. Palaeogeography, Palaeoclimatology, Palaeoecology 491:137-151. DOI: 10.1016/j.palaeo.2017.12.003.

Hitchcock E. 1858. A Report on the Sandstone of the Connecticut Valley, Especially Its Fossil Footmarks, Made to the Government of the Commonwealth of Massachusetts. Boston: William White.

Hitchcock E. 1865. Supplement to the Ichnology of New England. A Report to the Government of Massachusetts, in 1863. Boston: Wright and Potter State Printers.

Peer) reviewing PDF | (2020:09:52634:1:1:NEW 19 Nov 2020) 
1010 Hunt AP, Lucas SG. 2006a. The significance of the St. George Dinosaur Discovery Site at

1011

1012

1013

1014

1015

1016

1017

1018

1019

1020

1021

1022

1023

1024

1025

1026

1027

1028

1029

1030

1031

1032

1033

1034

1035

1036

1037

1038

1039

1040

1041

1042

1043

1044

1045

1046

1047

1048

1049 Johnson Farm: a Jurassic Konzentrat-Ichnolagerstätte, Utah, U.S.A. In: Harris JD, Lucas SG, Spielmann JA, Lockley MG, Milner ARC, Kirkland JI, eds. The Triassic-Jurassic Terrestrial Transition. New Mexico Museum of Nature and Science Bulletin 37:282-288.

Hunt AP, Lucas SG. 2006b. Triassic-Jurassic tetrapod ichnofacies. In: Harris JD, Lucas SG, Spielmann JA, Lockley MG, Milner ARC, Kirkland JI, eds. The Triassic-Jurassic Terrestrial Transition. New Mexico Museum of Nature and Science Bulletin 37:12-22.

Hunt AP, Lucas SG 2006c. Tetrapod ichnofacies: a new paradigm. Ichnos 14: 59-68. DOI:10.1080/10420940601006826.

Imaizumi R. 1967. On some Lebensspuren from the Tatsunokuchi Formation at Tatsunokuchi Gorge, Sendai, Miyagi Prefecture. In: Commemorative Association of Prof. Ichirō Hayasaka's $76^{\text {th }}$ Birthday, ed. Contributions to Celebrate Prof. Ichirō Hayasaka's $76^{\text {th }}$ Birthday. Kanazawa: Commemorative Association of Prof. Ichirō Hayasaka's $76^{\text {th }}$ Birthday, 205-210.

International Commission on Zoological Nomenclature. 1999. International Code of Zoological Nomenclature, Fourth Edition. London: The International Trust for Zoological Nomenclature.

Karasawa H, Okumura Y, Naruse A. 1990. Discovery of crab footprints from the Miocene Mizunami Group, central Japan. Bulletin of the Mizunami Fossil Museum 17:93-96.

Karasawa H, Schweitzer CE, Feldmann RM. 2013. Phylogeny and systematics of extant and extinct lobsters. Journal of Crustacean Biology 33:78-123. DOI: 10.1163/1937240X00002111.

King OA, Stimson MR, Lucas SG. 2019. The ichnogenus Kouphichnium and related xiphosuran traces from the Steven C. Minkin Paleozoic footprint site (Union Chapel Mines), Alabama, USA: ichnotaxonomic and paleoenvironmental implications. Ichnos 26:266302. DOI: $10.1080 / 10420940.2018 .1561447$.

Kirkland JI, Milner ARC. 2006. The Moenave Formation at the St. George Dinosaur Discovery Site at Johnson Farm, St. George, southwestern Utah. In: Harris JD, Lucas SG, Spielmann JA, Lockley MG, Milner ARC, Kirkland JI, eds. The Triassic-Jurassic Terrestrial Transition. New Mexico Museum of Nature and Science Bulletin 37:289-309.

Kirkland JI, Milner ARC, Olsen PE, Hargrave JE. 2014. The Whitmore Point Member of the Moenave Formation in its type area in northern Arizona and its age and correlation with the section in St. George, Utah: evidence for two major lacustrine sequences. In: MacLean JS, Biek RF, Huntoon JE, eds. Geology of Utah's Far South. Utah Geological Association Publication 43:321-356.

Knecht RJ, Benner JS, Rogers DC, Ridge JC. 2009. Surculichnus bifurcauda n. igen., n. isp., a trace fossil from late Pleistocene glaciolacustrine varves of the Connecticut River Valley, USA, attributed to notostracan crustaceans based on neoichnological experimentation. Palaeogeography, Palaeoclimatology, Palaeoecology 272:232-239. DOI: 10.1016/j.palaeo.2008.10.013. 
1050 Kopaska-Merkel DC, Buta RJ. 2013. Field trip guidebook to the Steven C. Minkin Paleozoic

1051

1052

1053

1054

1055

1056

1057

1058

1059

1060

1061

1062

1063

1064

1065

1066

1067

1068

1069

1070

1071

1072

1073

1074

1075

1076

1077

1078

1079

1080

1081

1082

1083

1084

1085

1086

1087

1088

1089 footprint site, Walker County, Alabama. In: Lucas SG, DiMichele WA, Barrick JE, Schneider JW, Spielmann JA, eds. The Carboniferous-Permian Transition. New Mexico Museum of Natural History and Science Bulletin 60:178-198.

Kozur H. 1981. Weitere Beiträge zur Paläontologie und Stratigraphie des Perm. GeologischePaläontologische Mitteilungen, Innsbruck 11:243-257.

Kozur H. 1989. Biostratigraphic zonations in the Rotliegendes and their correlations. Acta Musei Reginaehradecensis S.A.: Scientiae Naturales 22:15-30.

Kozur HW, Lemone DV. 1995. New terrestrial arthropod trackways from the Abo Member (Sterlitamakian, Late Sakmarian, late Wolfcampian) of the Shalem Colony Section, Robledo Mountains, New Mexico. In: Lucas SG, Heckert AB, eds. Early Permian Footprints and Facies. New Mexico Museum of Natural History and Science Bulletin 6:107-113.

Kozur H, Löffler M, Sittig E. 1994. First evidence of Paleohelcura (arthropod trackway) in the Rotliegend of Europe: Neues Jahrbuch für Geologie und Paläontologie Monatshefte 1994:618-632. DOI: 10.1127/njgpm/1994/1994/618.

Kozur HW, Weems RE. 2010. The biostratigraphic importance of conchostracans in the continental Triassic of the northern hemisphere. In: Lucas SG, ed. The Triassic Timescale. Geological Society of London Special Publications 334:315-417. DOI: 10.1144/ SP334.13.

Labandeira CC, Beall BS. 1990. Arthropod terrestriality. In: Mikulic DG, ed. Arthropod Paleobiology: Short Courses in Paleobiology 3. Knoxville: Paleontological Society, 214256.

Lagnaoui A, Voigt S, Belahmira A, Saber H, Schneider JW, Hminna A. 2015. New ichnospecie of the ichnogenus Paleohelcura Gilmore, 1926 from Late Permian red-beds of Argana Basin (Western High Atlas Mountains, Morocco). In: Saber H, Lagnaoui A, Belahmira A, eds. Proceedings of Abstracts, $1^{\text {st }}$ International Congress on Continental Ichnology. Arabian Journal of Earth Sciences Special Issue ICCI-2015:52-54.

Lima JHD, Minter NJ, Netto RG. 2017. Insights from functional morphology and neoichnology for determining tracemakers: a case study of the reconstruction of an ancient glacial arthropod-dominated fauna. Lethaia 50:576-590. DOI: 10.1111/let.12214.

Lima JHD, Netto RG, Corrêa CG, Lavina ELC. 2015. Ichnology of deglaciation deposits from the Upper Carboniferous Rio do Sul Formation (Itararé Group, Paraná Basin) at centraleast Santa Catarina State (southern Brazil). Journal of South American Earth Sciences 63:137-148. DOI: 10.1016/j.jsames.2015.07.008.

Linck O. 1943. Die Buntsandstein-Kleinfährten von Nagold. (Limulidichnulus nagoldensis n. g. n. sp., Merostomichnites triassicus n. sp.). Neues Jahrbuch für Mineralogie, Geologie und Paläontologie Monatshefte Abt. B 1943:9-27.

Lockley MG, Kirkland JI, Milner ARC. 2004. Probable relationships between the Lower Jurassic crocodilomorph trackways of Batrachopus and Selenichnus: evidence and implications

PeerJ reviewing PDF | (2020:09:52634:1:1:NEW 19 Nov 2020) 
1090

1091

1092

1093

1094

1095

1096

1097

1098

1099

1100

1101

1102

1103

1104

1105

1106

1107

1108

1109

1110

1111

1112

1113

1114

1115

1116

1117

1118

1119

1120

1121

1122

1123

1124

1125

1126

1127

1128

based on new finds from the St. George area southwestern Utah. Ichnos 11:143-149.

DOI: $10.1080 / 10420940490442340$.

Lomax DE, Racay CA. 2012. A long mortichnial trackway of Mesolimulus walchi from the Upper Jurassic Solnhofen lithographic limestone near Wintershof, Germany. Ichnos 19:175-183. DOI: 10.1080/10420940.2012.702704.

Lucas SG, Lerner AJ, Milner ARC, Lockley MG. 2006a. Lower Jurassic invertebrate ichnofossils from a clastic lake margin, Johnson Farm, southwestern Utah. In: Harris JD, Lucas SG, Spielmann JA, Lockley MG, Milner ARC, Kirkland JI, eds. The TriassicJurassic Terrestrial Transition. New Mexico Museum of Nature and Science Bulletin 37:128-136.

Lucas SG, Lerner AJ, Spielmann JA, Hunt AP. 2006b. Invertebrate ichnofossils from the Upper Triassic Bull Canyon Formation, east-central New Mexico. In: Harris JD, Lucas SG, Spielmann JA, Lockley MG, Milner ARC, Kirkland JI, eds. The Triassic-Jurassic Terrestrial Transition. New Mexico Museum of Nature and Science Bulletin 37:118-121.

Lucas SG, Lerner AJ, Voigt S. 2013. Scorpionid resting trace from the Lower Permian of southern New Mexico, USA. Ichnos 20:195-201. DOI: 10.1080/10420940.2013.845096.

Lucas SG, Minter NJ, Spielmann JA, Hunt AP, Braddy SJ. 2005b. Early Permian ichnofossil assemblage from the Fra Cristobal Mountains, southern New Mexico. In: Lucas SG, Zeigler KE, Spielmann JA, eds. The Permian of Central New Mexico. New Mexico Museum of Nature and Science Bulletin 31:140-150.

Lucas SG, Minter NJ, Spielmann JA, Smith JA, Braddy SJ. 2005a. Early Permian ichnofossils from the northern Caballo Mountains, Sierra County, New Mexico. In: Lucas SG, Zeigler KE, Spielmann JA, eds. The Permian of Central New Mexico. New Mexico Museum of Nature and Science Bulletin 31:151-162.

Lucas SG, Tanner LH. 2006. The Springdale Member of the Kayenta Formation, Lower Jurassic of Utah-Arizona. In: Harris JD, Lucas SG, Spielmann JA, Lockley MG, Milner ARC, Kirkland JI, eds. The Triassic-Jurassic Terrestrial Transition. New Mexico Museum of Nature and Science Bulletin 37:71-76.

Lull RS. 1953. Triassic life of the Connecticut Valley. State of Connecticut State Geological and Natural History Survey Bulletin 81:1-336.

Luque J, Feldmann RM, Vernygora O, Schweitzer CE, Cameron DB, Kerr KA, Vega FJ, Duque A, Strange M, Palmer AR, Jaramillo, C. 2019. Exceptional preservation of midCretaceous marine arthropods and the evolution of novel forms via heterochrony. Science Advances 5:eaav3875. DOI: 10.1126/sciadv.aav3875.

Machalski M, Machalska K 1994. Arthropod trackways, “Diplichnites” triassicus (Linck, 1943), from the Lower Triassic (Buntsandstein) fluvial deposits of the Holy Cross Mts, central Poland. Acta Geologica Polonica 44:267-275.

MacNaughton RB, Cole JM, Dalrymple RW, Braddy SJ, Briggs DEG, Lukie, TD. 2002. First steps on land: arthropod trackways in Cambrian-Ordovician eolian sandstone, 
1129

1130

1131

1132

1133

1134

1135

1136

1137

1138

1139

1140

1141

1142

1143

1144

1145

1146

1147

1148

1149

1150

1151

1152

1153

1154

1155

1156

1157

1158

1159

1160

1161

1162

1163

1164

1165

1166

1167

southeastern Ontario, Canada. Geology 30:391-394. DOI: 10.1130/0091-

7613(2002)030<0391:FSOLAT>2.0.CO;2.

Martin AJ. 2013. Life Traces of the Georgia Coast: Revealing the Unseen Lives of Plants and Animals. Bloomington: Indiana University Press.

Martin AJ, Rich TH, Poore GCB, Schultz MB, Austin CM, Kool L, Vickers-Rich P. 2008. Fossil evidence in Australia for oldest known freshwater crayfish of Gondwana. Gondwana Research 14:287-296. DOI: 10.1016/j.gr.2008.01.002.

Matsuoka K, Karasawa H, Yoshimura A, Ieda K. 1993. Footprint fossils discovered from the Miocene Shidara Group, Toei-cho, Kitashitara-gun, Aichi Prefecture, Japan. Science Reports of the Toyohashi Museum of Natural History 3:27-36.

Matthew GF. 1910. Remarkable forms of the Little River Group. Transactions of the Royal Society of Canada 4:115-125.

McNamara KJ. 2014. Early Paleozoic colonisation of the land: evidence from the Tumblagooda Sandstone, southern Carnarvon Basin, western Australia. W A Science-Journal of the Royal Society of Western Australia 97:111-132.

Melchor RN, Cardonatto MC. 2014. Insights on behavior of Late Paleozoic aquatic crustaceans (Pygocephalomorpha?): compound trace fossils from western Argentina. Ichnos 21:7699. DOI: $10.1080 / 10420940.2013 .879868$.

Miller GL, Ash SR. 1988. The oldest freshwater decapod crustacean, from the Triassic of Arizona. Palaeontology 31:273-279.

Miller RF. 1996. Location of trace fossils and problematica of George Frederic Matthew from

Part W, Treatise on Invertebrate Paleontology. Journal of Paleontology 70:161-171. DOI: $10.1017 / \mathrm{S} 0022336000023210$.

Miller SA. 1880. Silurian ichnolites, with definitions of new genera and species. Journal of the Cincinnati Society of Natural History 2(1):217-222.

Milner ARC, Birthisel TA, Kirkland JI, Breithaupt BH, Matthews NA, Lockley MG, Santucci VL, Gibson SZ, DeBlieux DD, Hurlbut M, Harris JD, Olsen PE. 2012. Tracking Early Jurassic dinosaurs across southwestern Utah and the Triassic-Jurassic transition. In: Bonde JW, Milner ARC, eds. Field Trip Guide Book for the 71 st Annual Meeting of the Society of Vertebrate Paleontology. Nevada State Museum Paleontological Papers 1:1107.

Milner ARC, Harris JD, Lockley MG, Kirkland JI, Matthews NA. 2009. Bird-like anatomy, posture, and behavior revealed by an Early Jurassic theropod dinosaur resting trace. PLoS ONE 4:e4591. DOI: 10.1371/journal.pone.000459.

Milner ARC, Lockley MG, Johnson SB. 2006. The story of the St. George Dinosaur Discovery Site at Johnson Farm: an important new Lower Jurassic dinosaur tracksite from the Moenave Formation of southwestern Utah. In: Harris JD, Lucas SG, Spielmann JA, Lockley MG, Milner ARC, Kirkland JI, eds. The Triassic-Jurassic Terrestrial Transition. New Mexico Museum of Nature and Science Bulletin 37:329-345. 
1168

1169

1170

1171

1172

1173

1174

1175

1176

1177

1178

1179

1180

1181

1182

1183

1184

1185

1186

1187

1188

1189

1190

1191

1192

1193

1194

1195

1196

1197

1198

1199

1200

1201

1202

1203

1204

1205

Milner ARC, Lockley MG, Kirkland JI. 2006. A large collection of well-preserved theropod dinosaur swim tracks from the Lower Jurassic Moenave Formation, St. George, Utah. In: Harris JD, Lucas SG, Spielmann JA, Lockley MG, Milner ARC, Kirkland JI, eds. The Triassic-Jurassic Terrestrial Transition. New Mexico Museum of Nature and Science Bulletin 37:315-328.

Minter NJ, Braddy SJ. 2009. Ichnology of an Early Permian intertidal flat: the Robledo Mountains Formation of southern New Mexico, USA. Special Papers in Palaeontology 82:1-107.

Minter NJ, Braddy SJ, Davis RB. 2007. Between a rock and a hard place: arthropod trackways and ichnotaxonomy. Lethaia 40:365-375. DOI: 10.1111/j.1502-3931.2007.00035.x.

Minter NJ, Buatois LA, Mángano MG, Davies NS, Gibling MR, Labandeira C. 2016b. The establishment of continental ecosystems. In: Mángano MG, Buatois LA, eds. The TraceFossil Record of Major Evolutionary Events Vol. 1: Precambrian and Paleozoic. Dordrecht: Springer Science+Business Media, 205-324. DOI: 10.1007/978-94-017-96002 -6.

Minter NJ, Buatois LA, Mángano MG, MacNaughton RB, Davies NS, Gibling MR. 2016a. The prelude to continental invasion. In: Mángano MG, Buatois LA, eds. The Trace-Fossil Record of Major Evolutionary Events Vol. 1: Precambrian and Paleozoic. Dordrecht: Springer Science+Business Media, 157-204. DOI: 10.1007/978-94-017-9600-2_5.

Minter NJ, Krainer K, Lucas SG, Braddy SJ, Hunt AP. 2007. Palaeoecology of an Early Permian playa lake trace fossil assemblage from Castle Peak, Texas, USA. Palaeogeography, Palaeoclimatology, Palaeoecology 246:390-423. DOI: 10.1016/j.palaeo.2006.10.009.

Nopcsa FB. 1923. Die Familien der Reptilien. Forschritte der Geologie und Paläontologie 2:1210.

O'Brien LJ, Braddy SJ, Radley JD. 2009. A new arthropod resting trace and associated suite of trace fossils from the Lower Jurassic of Warwickshire, England. Palaeontology 52:10991112. DOI: 10.1111/j.1475-4983.2009.00901.x.

Olsen PE, Huber P. 1997. Stop 3: Triangle Brick Quarry. In: Clark TW, ed. TRIBI: Triassic Basin Initiative, Abstracts with Programs and Field Trip Guidebook. Durham: Duke University, 22-29.

Osgood RG Jr. 1975. The paleontological significance of trace fossils. In: Frey RW, ed. The Study of Trace Fossils. Berlin: Springer, 87-108. DOI: 10.1007/978-3-642-65923-2_6.

Owen R. 1852. Description of the impressions and foot-prints of the Protichnites from the Potsdam Sandstone of Canada. Quarterly Journal of the Geological Society 8:214-225. DOI: 10.1144/GSL.JGS.1852.008.01-02.26.

Packard AS. 1900. On supposed merostomatous and other Paleozoic arthropod trails, with notes on those of Limulus. Proceedings of the American Academy of Arts and Sciences 36(4):63-71.

Peer) reviewing PDF | (2020:09:52634:1:1:NEW 19 Nov 2020) 
1206 Parrish JT, Rasbury ET, Chan MA, Hasiotis ST. 2019. Earliest Jurassic U-Pb ages from

1207

1208

1209

1210

1211

1212

1213

1214

1215

1216

1217

1218

1219

1220

1221

1222

1223

1224

1225

1226

1227

1228

1229

1230

1231

1232

1233

1234

1235

1236

1237

1238

1239

1240

1241

1242

1243 carbonate deposits in the Navajo Sandstone, southeastern Utah, USA. Geology 47:10151019. DOI: $10.1130 / \mathrm{G} 46338.1$.

Pazos PJ. 2000. Trace fossils and facies in glacial to postglacial deposits from the Paganzo basin (Late Carboniferous), central Precordillera, Argentina. Ameghiniana 37:23-38.

Peixoto B de CPeM, Mángano MG, Minter NJ, dos Reis Fernandes LB, Fernandes MA. 2020. A new insect trackway from the Upper Jurassic-Lower Cretaceous eolian sandstones of São Paulo State, Brazil: implications for reconstructing desert paleoecology. PeerJ 8:ee8880. DOI: 10.7717 peerj. 8880 .

Pemberton SG, MacEachern JA, Gingras MK. 2007. The antecedents of invertebrate ichnology in North America: the Canadian and Cincinnati schools. In: Miller W III, ed. Trace Fossils: Concepts, Problems, Prospects. Amsterdam: Elsevier, 14-31.

Perrier V, Vannier J, Racheboeuf PR, Charbonnier S, Chabard D, Sotty D. 2006. Syncarid crustaceans from the Montceau Lagerstätte (Upper Carboniferous; France). Palaeontology 49:647-672. DOI: 10.1111/j.1475-4983.2006.00553.x.

Pirrie D, Feldmann RM, Buatois LA. 2004. A new decapod trackway from the Upper Cretaceous, James Ross Island, Antarctica. Palaeontology 47:1-12. DOI: 10.1111/j.00310239.2004.00343.x.

Pollard JE. 1985. Isopodichnus, related arthropod trace fossils and notostracans from Triassic fluvial sediments. Transactions of the Royal Society of Edinburgh 76:273-285. DOI: 10.1017/S026359330001049X.

Pollard JE. 1995. John Smith's discoveries of trace fossils from Old Red Sandstone and Carboniferous rocks of southwest Scotland. In: Ayrshire Archaeological and Natural History Society, ed. John Smith of Dalry: Geologist, Antiquarian and Natural Historian Part 1-Geology. Ayrshire: Walker \& Connell, Ltd., 30-39.

Pollard J, Selden P, Watts S. 2008. Trace fossils of the arthropod Camptophyllia from the Westphalian (Carboniferous) of Lancashire, UK and their palaeoenvironmental context. Palaeogeography, Palaeoclimatology, Palaeoecology 270:399-406. DOI: 10.1016/j.palaeo.2008.01.032.

Pollard JE, Steel RJ, Undersrud E. 1982. Facies sequences and trace fossils in lacustrine/fan delta deposits, Hornelen Basin (M. Devonian), western Norway. Sedimentary Geology 32:6387. DOI: $10.1016 / 0037-0738(82) 90014-8$.

Pollard JE, Walker EF. 1984. Reassessment of sediments and trace fossils from Old Red Sandstone (Lower Devonian) of Dunure, Scotland, described by John Smith (1909). Geobios 17:567-576. DOI:10.1016/S0016-6995(84)80029-7.

Porter ML, Pérez-Losada M, Crandall KA. 2005. Model-based multi-locus estimation of decapod phylogeny and divergence times. Molecular Phylogenetics and Evolution 37:355-369. DOI: 10.1016/j.ympev.2005.06.021. 
1244

1245

1246

1247

1248

1249

1250

1251

1252

1253

1254

1255

1256

1257

1258

1259

1260

1261

1262

1263

1264

1265

1266

1267

1268

1269

1270

1271

1272

1273

1274

1275

1276

1277

1278

1279

1280

1281

Poschmann M, Braddy SJ. 2010. Eurypterid trackways from Early Devonian tidal facies of Alken an der Mosel (Rheinisches Schiefergebirge, Germany). Palaeobiodiversity and Palaeoenvironments 90:111-124. DOI: 10.1007/s12549-010-0024-2.

Rainforth E. 2005. Ichnotaxonomy of the Fossil Footprints of the Connecticut Valley (Early Jurassic, Newark Supergroup, Connecticut and Massachusetts). D. Phil. Dissertation, Columbia University.

Rainforth EC, Lockley MG. 1996. Tracking life in a Lower Jurassic desert: vertebrate tracks and other traces from the Navajo Sandstone. In: Morales M, ed. The Continental Jurassic. Museum of Northern Arizona Bulletin 60:285-289.

Richter R. 1954. Fährte eines "Risenkrebses" im Rheinischen Schiefergebirge. Natur und Volk 84:261-269.

Rode AL, Babcock LE. 2003. Phylogeny of fossil and extant crayfish and some closely related nephropid lobsters. Journal of Crustacean Biology 23:418-435. DOI: 10.1163/2002197599990351.

Sadler CJ. 1993. Arthropod trace fossils from the Permian De Chelly Sandstone, northeastern Arizona. Journal of Paleontology 67:240-249. DOI: 10.1017/S0022336000032169.

Santucci VL, Kirkland JI. 2010. An overview of National Park Service paleontological resources from the parks and monuments in Utah. In: Sprinkel DA, Chidsey TC Jr, Anderson PB, eds. Geology of Utah's Parks and Monuments, $3^{\text {rd }}$ Ed. Utah Geological Association Publication 28:589-623.

Savage NM. 1971. A varvite ichnocoenosis from the Dwyka series of Natal. Lethaia 4:217-233. DOI: $10.1111 /$ j.1502-3931.1971.tb01290.x.

Schram FR. 2001. Phylogeny of decapods: moving towards a consensus. Hydrobiologia 449:120. DOI: $10.1023 / \mathrm{a}: 1017543712119$.

Schram FR, Dixon CJ. 2004. Decapod phylogeny: addition of fossil evidence to a robust morphological cladistic data set. Bulletin of the Mizunami Fossil Museum 31:1-19.

Schweitzer CE, Feldmann RM, Garassino A, Karasawa H, Schweiger G. 2010. Systematic List of Fossil Decapod Crustacean Species. Leiden: Brill NV. DOI: 10.1163/ej.9789004178915.i-222.

Seilacher A. 2007. Trace Fossil Analysis. Berlin: Springer. DOI: 10.1007/978-3-540-47226-1.

Seilacher A. 2008. Biomats, biofilms, and bioglue as preservational agents for arthropod trackways. Palaeogeography, Palaeoclimatology, Palaeoecology 270:252-257. DOI: 10.1016/j.palaeo.2008.07.011.

Selden PA, Nudds JR. 2012. Evolution of Fossil Ecosystems, $2^{\text {nd }}$ Ed. Amsterdam: Elsevier.

Shen H, Braband A, Scholtz, G. 2015. The complete mitogenomes of lobsters and crayfish (Crustacea: Decapoda: Astacidea) reveal surprising differences in closely related taxa and convergences to Priapulida. Journal of Zoological Systematics and Evolutionary Research 53:273-281. DOI: 10.1111/jzs.12106.

Peer) reviewing PDF | (2020:09:52634:1:1:NEW 19 Nov 2020) 
1282

1283

1284

1285

1286

1287

1288

1289

1290

1291

1292

1293

1294

1295

1296

1297

1298

1299

1300

1301

1302

1303

1304

1305

1306

1307

1308

1309

1310

1311

1312

1313

1314

1315

1316

1317

1318

1319

Shen Y-B. 2003. Shrimps. In: Chang M-M, Chen P-J, Wang Y-Q, Wang Y, Miao D-S, eds. The Jehol Biota: The Emergence of Feathered Dinosaurs, Beaked Birds and Flowering Plants. Shanghai: Shanghai Scientific \& Technical Press, 53-57.

Shillito AP, Davies NS. 2018. Death near the shoreline, not life on land: Ordovician arthropod trackways in the Borrowdale Volcanic Group, UK. Geology 47:55-58. DOI: 10.1130/G45663.1.

Shu W, Tong J, Tian L, Benton MJ, Chu D, Yu J, Guo W. 2018. Limuloid trackways from Permian-Triassic continental successions of North China. Palaeogeography, Palaeoclimatology, Palaeoecology 508:71-90. DOI: 10.1016/j.palaeo.2018.07.022.

Smith A, Braddy SJ, Marriott SB, Briggs DEG. 2003. Arthropod trackways from the Early Devonian of South Wales: a functional analysis of producers and their behaviour. Geological Magazine 140:63-72. DOI: 10.1017/S0016756802006982.

Smith DM. 2012. Exceptional preservation of insects in lacustrine environments. Palaios 27:346-353. DOI: 10.2110/palo.2011.p11-107r.

Smith J. 1909. Upland Fauna of the Old Red Sandstone Formation of Carrick, Ayrshire. Kilwinning: A.W. Cross.

Steiner M. 2014a. Age of Lower Jurassic Springdale Sandstone of southwestern Utah from its magnetic polarity sequence. Volumina Jurassica 12(2):23-30. DOI: 10.5604/17313708.1130124.

Steiner M. 2014b. New magnetostratigraphy and paleopole from the Whitmore Point Member of the Moenave Formation at Kanab, Utah. Volumina Jurassica 12(2):13-22. DOI: $10.5604 / 17313708.1130122$.

Stern D, Crandall KA. 2015. Phylogenetic estimate of the freshwater crayfish (Decapoda: Astacidea) using morphology and molecules. In: Kawai T, Faulkes Z, Scholtz G, eds. Freshwater Crayfish: A Global Overview. Boca Raton: CRC Press, 298-309.

Stimson M, MacRae A, Calder J, Hebert B, Reid D, Reid L. 2018. The Diplichnites aenigma enigma: ichnotaxonomic implications of a restudy of Dawson's type locality at Coal Mine Point, Joggins, Nova Scotia. $1^{\text {st }}$ Joggins Research Symposium, Joggins Fossil Institute, Abstracts. Atlantic Geology 54:487. DOI: 10.4138/atlgeol.2018.016.

Suarez CA, Knobbe TK, Crowley JL, Kirkland JI, Milner ARC. 2017. A chronostratigraphic assessment of the Moenave Formation, USA using $\mathrm{C}$-isotope chemostratigraphy and detrital zircon geochronology: implications for the terrestrial end Triassic extinction. Earth and Planetary Science Letters 475:83-93. DOI: 10.1016/j.eps1.2017.07.028.

Tanner LH, Lucas SG. 2009. The Whitmore Point Member of the Moenave Formation: Early Jurassic dryland lakes on the Colorado Plateau, southwestern USA. Volumina Jurassica 6(1):11-21.

Tasch P. 1969. New observations on the notostracan Triops longicaudatus in natural and cultural situations. Transactions of the Kansas Academy of Science 72:323-329.

Peer) reviewing PDF | (2020:09:52634:1:1:NEW 19 Nov 2020) 
1320

1321

1322

1323

1324

1325

1326

1327

1328

1329

1330

1331

1332

1333

1334

1335

1336

1337

1338

1339

1340

1341

1342

1343

1344

1345

1346

1347

1348

1349

1350

1351

1352

1353

1354

1355

1356

1357

1358

Taylor RS, Schram FR, Shen Y-B. 1999. A new crayfish family (Decapoda: Astacida) from the Upper Jurassic of China, with a reinterpretation of other Chinese crayfish taxa. Paleontological Research 3:121-136. DOI: 10.2517/prpsj.3.121.

Trewin NH, McNamara KJ. 1994. Arthropods invade the land: trace fossils and palaeoenvironments of the Tumblagooda Sandstone (?Late Silurian) of Kalbarri, western Australia. Transactions of the Royal Society of Edinburgh: Earth Sciences 85:177-210. DOI: 10.1017/S026359330000359X.

Trusheim F. 1931. Aktuo-paläontologische Beobachtungen an Triops cancriformis Schaeffer (Crust. Phyll.). Senckenbergiana 13:234-243.

Uchman A, Gaździcki A, Błażejowski B. 2018. Arthropod trace fossils from Eocene cold climate continental strata of King George Island, West Antarctica. Acta Palaeontologica Polonica 63:383-396. DOI: 10.4202/app.00467.2018.

Uchman A, Hu B, Wang Y, Song H. 2011. The trace fossil Diplopodichnus from the Lower Jurassic lacustrine sediments of central China and the isopod Armadillidium vulgare (pillbug) Lebensspuren as its Recent analogue. Ichnos 18:147-155. DOI: 10.1080/10420940.2011.601372.

Uchman A, Kazakauskas V, Gaigalas A. 2009. Trace fossils from Late Pleistocene varved lacustrine sediments in eastern Lithuania. Palaeogeography, Palaeoclimatology, Palaeoecology 272:199-211. DOI: 10.1016/j.palaeo.2008.08.003.

Uchman A, Vrenozi B, Muceku B. 2018. Spider burrows in ichnological context: a review of literature data and burrows of the wolf spider Trochosa hispanica Simon, 1870 from Albania. Rendiconti Lincei. Scienze Fisiche e Naturali 29:67-79. DOI: 10.1007/s12210017-0662-7.

Urreta MBA. 1989. The Cretaceous decapod Crustacea of Argentina and the Antarctic Peninsula. Palaeontology 32:499-552.

Viohl G. 1998. Die Solnhofener Plattenkalke-Entstehung und Lebensräume. Archaeopteryx 16:37-68.

Walker EF. 1985. Arthropod ichnofauna of the Old Red Sandstone at Dunure and Montrose, Scotland. Transactions of the Royal Society of Edinburgh: Earth Sciences 76:287-297. DOI: $10.1017 / \mathrm{S} 0263593300010506$.

Walker SE, Holland SM, Gardiner L. 2003. Coenobichnus currani (new ichnogenus and ichnospecies): fossil trackway of a land hermit crab, early Holocene, San Salvador, Bahamas. Journal of Paleontology 77:576-582. DOI: 10.1017/S0022336000044255.

Walter H. 1985. Zur Ichnologie des Pleistozäns von Liebegast. Freiberger Forschungshefte C 400:101-116.

Webby BD. 1983. Lower Ordovician arthropod trace fossils from western New South Wales. Proceedings of the Linnean Society of New South Wales 107:61-76.

Wolfe JM, Breinholt JW, Crandall KA, Lemmon AR, Lemmon EM, Timm LE, Siddall ME, Bracken-Grissom HD. 2019. A phylogenomic framework, evolutionary timeline and 
genomic resources for comparative studies of decapod crustaceans. Proceedings of the 


\section{FIGURE CAPTIONS}

1362

1363

1364

1365

1366

1367

1368

1369

1370

1371

1372

1373

1374

1375

1376

1377

1378

1379

1380

1381

1382

1383

1384

1385

1386

1387

1388

1389

1390

1391

1392

1393

1394

1395

1396

1397

1398

1399

1400
Figure 1: Location of the St. George Dinosaur Discovery Site at Johnson Farm. (A) Map showing the location of the St. George Dinosaur Discovery Site in St. George, Utah. (B) The museum at the St. George Dinosaur Discovery Site. Photograph by Jerald D. Harris.

Figure 2: Stratigraphic section at and immediately around the St. George Dinosaur Discovery Site (SGDS) in St. George, Utah. Arthropod locomotory trackway SGDS 1290 comes from the "Top Surface Tracksite" layers of the Johnson Farm Sandstone Bed (red arrows).

Figure 3: Arthropod locomotory ichnofossil SGDS 1290. (A) Photograph of specimen; scale in mm. (B) Schematic diagram of specimen. Arrow indicates direction of movement. $\mathrm{L}=$ left track; $\mathrm{R}=$ right track; Ov = overtracks. Numbers indicate position of tracks in sequence from posterior to anterior. Photograph by Andrew R.C. Milner. (C) Schematic diagram of specimen, showing examples of how measurements were taken. IEW = external width between paramedial impressions; IIW = internal width between paramedial impressions; IW = paramedial impression width; TL = track length; TTI = distance between track and adjacent paramedial impression; TW = track width. (D) Photograph of extant crayfish walking trace made in saturated, very fine sand for comparison to fossil in (A); scale in $\mathrm{cm}$. Arrow indicates direction of travel; photograph rotated to have the same orientation as (A). Modified from Fairchild \& Hasiotis (2011: fig. 4E); reproduced with permission from SEPM.

Figure 4: Schematic diagrams of locomotory (presumably walking) ichnofossils attributed to arthropods (A-MM) and extant walking traces made by arthropods (NN-OO) compared to SGDS 1290 (PP). Diagrams not to scale. (A) Acanthichnus cursorius (traced from Hitchcock, 1858). (B) Asaphoidichnus trifidus (traced from Miller, 1880). (C) Bifurculapes laqueatus (traced from Getty, 2016). (D) Coenobichnus currani (traced from Walker, Holland \& Gardiner, 2003). (E) Copeza triremis (traced from Hitchcock, 1858). (F) Danstairia congesta (traced from Walker, 1985). (G) Diplichnites aenigma (traced from Dawson, 1873). (H) Diplichnites gouldi Type A (traced from Trewin and McNamara, 1994). (I) Eisenachichnus inaequalis (traced from Kozur, 1981). (J) Foersterichnus rossensis (traced from Pirrie, Feldmann \& Buatois, 2004). (K) Hamipes didactylus (traced from Getty, 2018). (L) Laterigradus lusitanicus (traced from de Carvalho et al., 2016). (M) Lithographus hieroglyphicus (traced from Hitchcock, 1858). (N) Maculichna varia (traced from Anderson, 1975a). (O) Merostomichnites narrangansettensis (traced from Packard, 1900). (P) Mirandaichnium famatinense (traced from Aceñolaza, 1978). (Q) Octopodichnus didactylus (traced from Gilmore, 1927). (R) Petalichnus multipartatus (Miller, 1880). (S) Pterichnus centipes (traced from Hitchcock, 1865). (T) Tasmanadia twelvetreesi (traced from Glaessner, 1957). (U) Umfolozia sinuosa (traced from Anderson, 1981). (V) Kouphichnium lithographicum (traced from Gaillard, 2011). (W) “Merostomichnites isp." (traced from Hanken \& Stormer, 1975). (X) 
1401

1402

1403

1404

1405

1406

1407

1408

1409

1410

1411

1412

1413

1414
Oniscoidichnus filiciformis (traced from Brady, 1947). (Y) Palmichnium antarcticum (traced from Braddy \& Milner, 1998). (Z) Paleohelcura tridactyla (traced from Gilmore, 1926). (AA) Protichnites septemnotatus (traced from Owen, 1852). (BB) Robledoichnus

lucasi (traced from Kozur \& Lemone, 1995). (CC) Shalemichnus sittigi, half of trackway (traced from Kozur \& Lemone, 1995). (DD) Stiallia berriana (traced from Smith, 1909). (EE) Stiaria quadripedia (traced from Walker, 1985). (FF) Mitchellichnus ferrydenensis (traced from Walker, 1985). (GG) Keircalia multipedia (traced from Walker, 1985). (HH) Danstairia vagusa (traced from Walker, 1985). (II) Glaciichnium liebegastensis (traced from Walter, 1985). (JJ) Warvichnium ulbrichi (traced from Walter, 1985). (KK) Siskemia bipediculus (traced from Walker, 1985). (LL) Siskemia elegans (traced from Walker, 1985). (MM) Siskemia latavia (traced from Walker, 1985). (NN) Extant notostracan traces (traced from Knecht et al., 2009). (OO) Extant crayfish trace in saturated, very fine sand (traced from Fairchild \& Hasiotis, 2011). (PP) SGDS 1290. 


\section{TABLE CAPTIONS}

1416

1417

Table S1: Measurements (in mm) of arthropod locomotory ichnofossil SGDS 1290.

1418

Measurements in parentheses are approximated based on faint portions of paramedial impressions. See Fig. 3C for a depiction of the measurements taken. 
Figure 1

Location of the St. George Dinosaur Discovery Site at Johnson Farm.

(A) Map showing the location of the St. George Dinosaur Discovery Site in St. George, Utah.

(B) The museum at the St. George Dinosaur Discovery Site. Photograph by Jerald D. Harris.
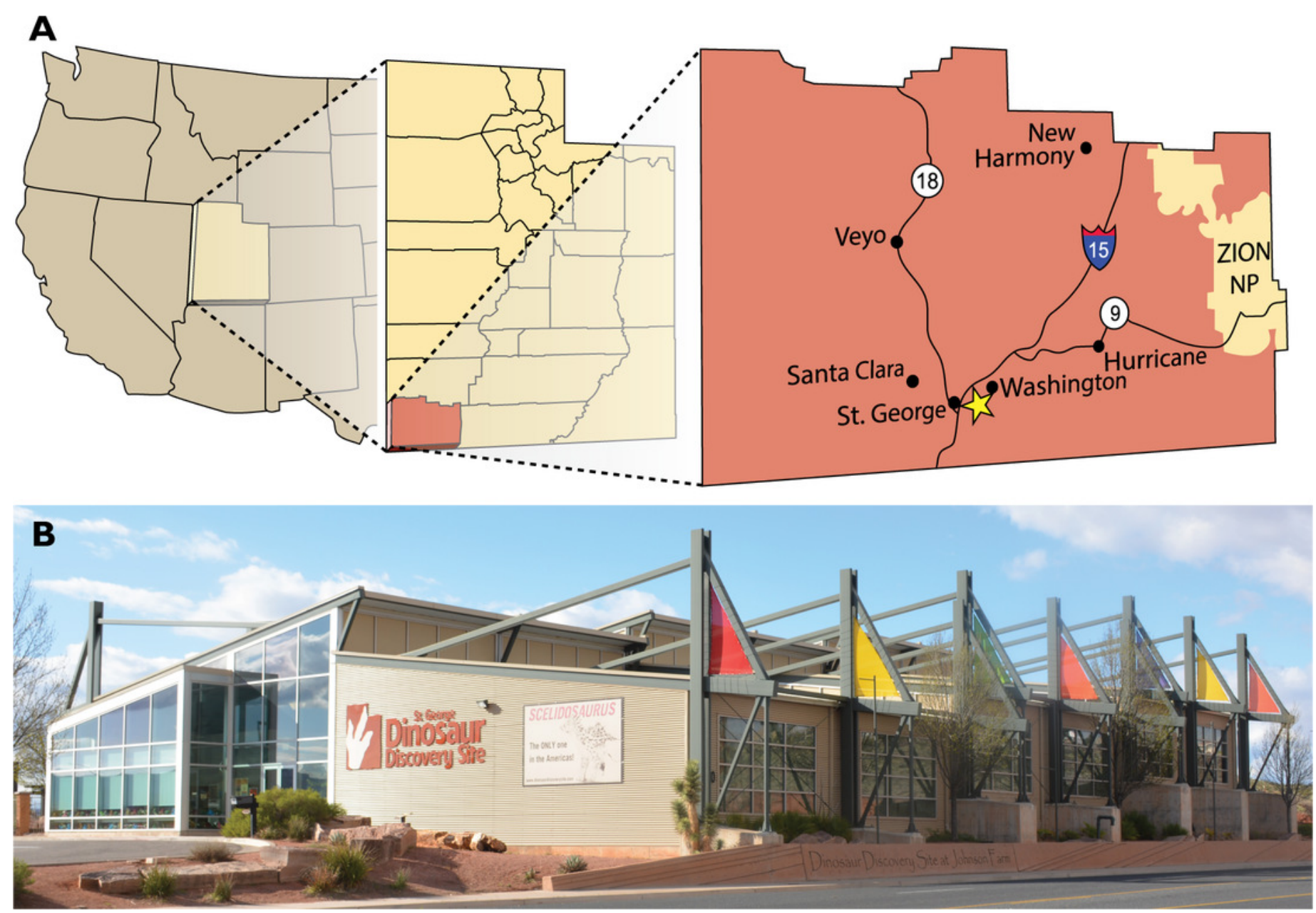
Figure 2

Stratigraphic section at and immediately around the St. George Dinosaur Discovery Site (SGDS) in St. George, Utah.

Arthropod locomotory trackway SGDS 1290 comes from the "Top Surface Tracksite" layers of the Johnson Farm Sandstone Bed (red arrows). 


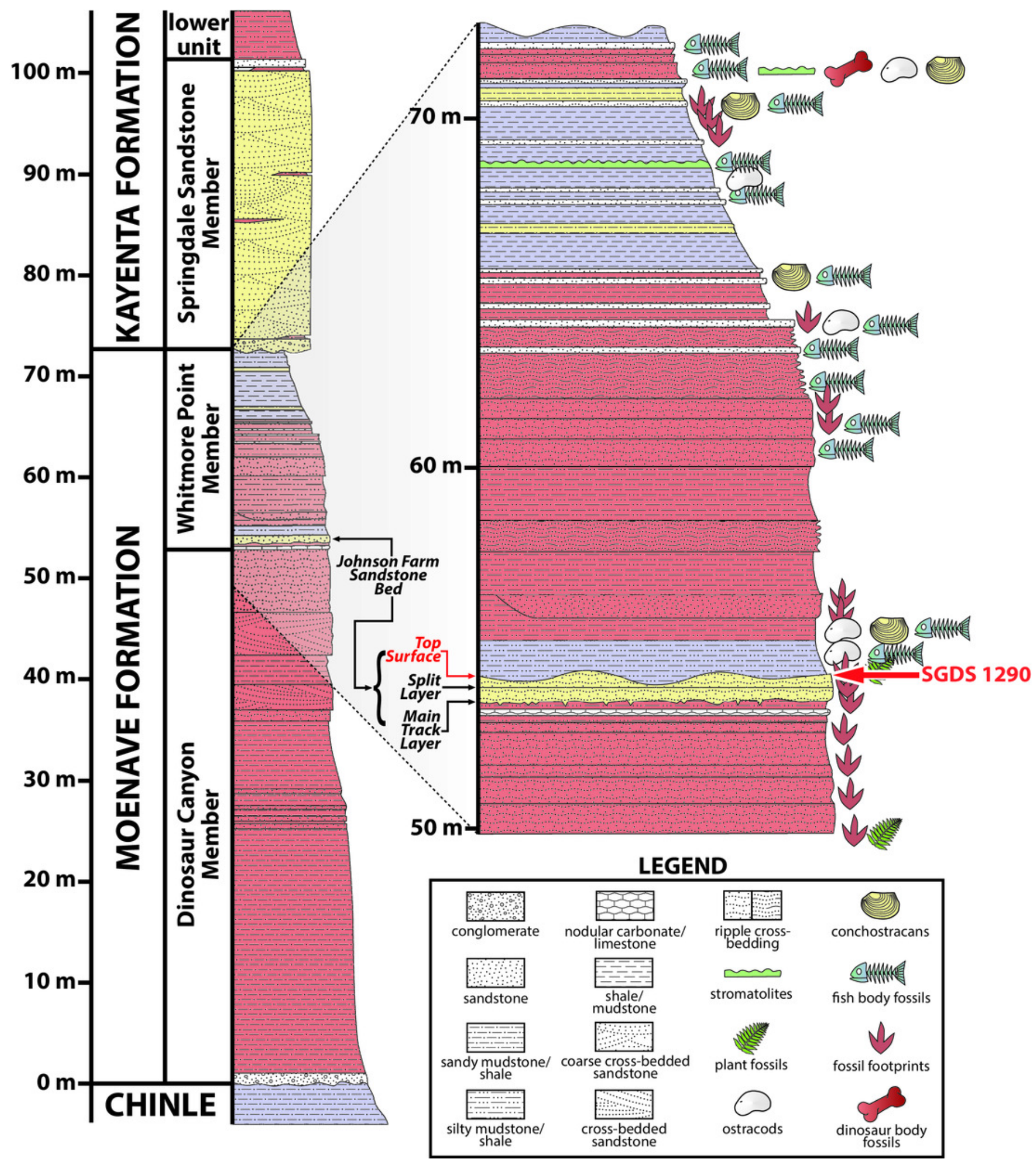




\section{Figure 3}

Arthropod locomotory ichnofossil SGDS 1290.

(A) Photograph of specimen; scale in $\mathrm{mm}$. (B) Schematic diagram of specimen. Arrow indicates direction of movement. $L=$ left track; $R=$ right track; Ov = overtracks. Numbers indicate position of tracks in sequence from posterior to anterior. Photograph by Andrew R.C. Milner. (C) Schematic diagram of specimen, showing examples of how measurements were taken. IEW = external width between paramedial impressions; IIW = internal width between paramedial impressions; IW = paramedial impression width; $\mathrm{TL}$ = track length; $\mathrm{TTI}=$ distance between track and adjacent paramedial impression; TW = track width. (D) Photograph of extant crayfish walking trace made in saturated, very fine sand for comparison to fossil in (A); scale in cm. Arrow indicates direction of travel; photograph rotated to have the same orientation as (A). Modified from Fairchild \& Hasiotis (2011: fig. 4E); reproduced with permission from SEPM. 

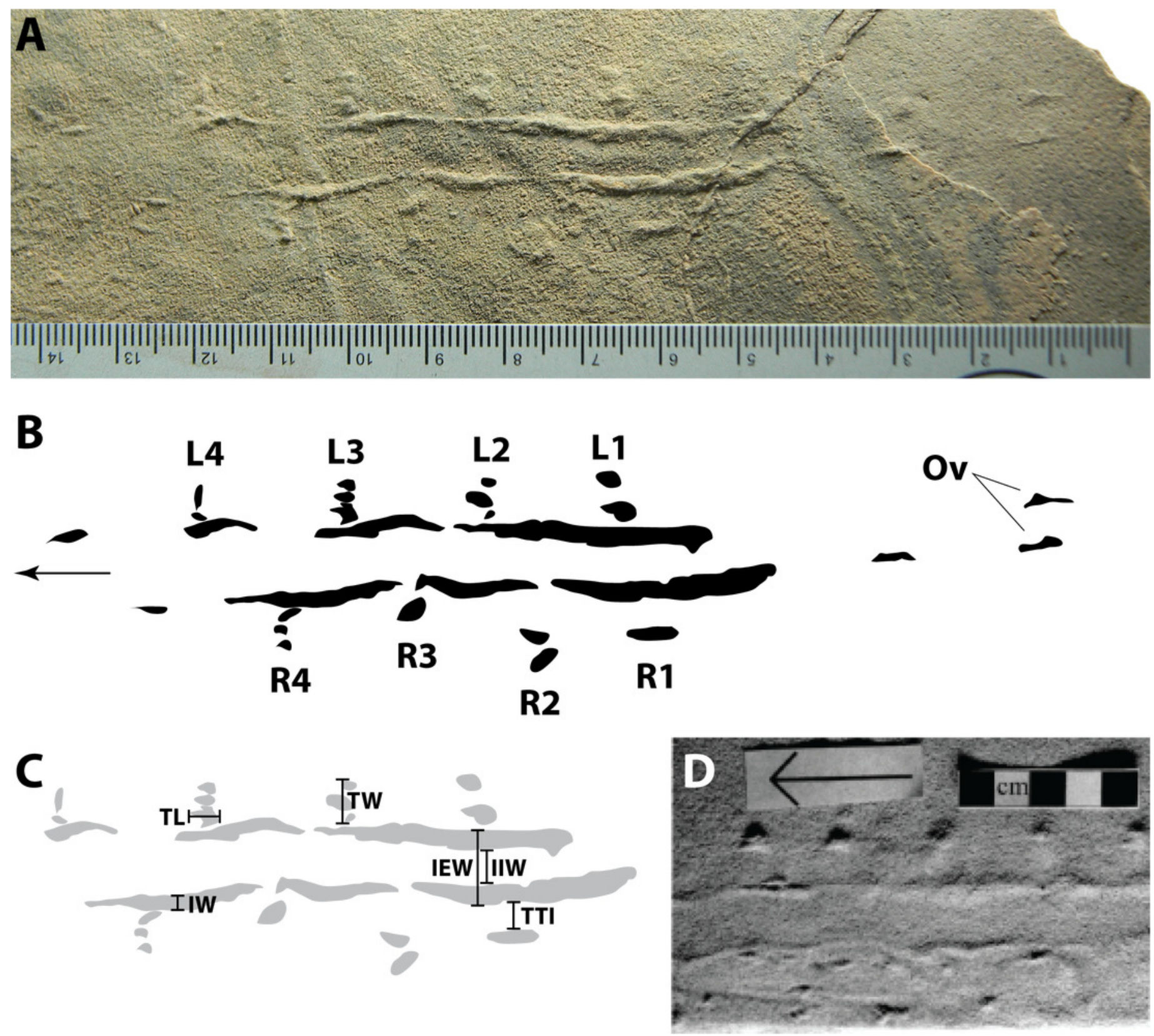


\section{Figure 4}

Schematic diagrams of locomotory (presumably walking) ichnofossils attributed to arthropods (A-MM) and extant walking traces made by arthropods (NN-OO) compared to SGDS 1290 (PP).

Diagrams not to scale. (A) Acanthichnus cursorius (traced from Hitchcock, 1858). (B) Asaphoidichnus trifidus (traced from Miller, 1880). (C) Bifurculapes laqueatus (traced from Getty, 2016). (D) Coenobichnus currani (traced from Walker, Holland \& Gardiner, 2003). (E) Copeza triremis (traced from Hitchcock, 1858). (F) Danstairia congesta (traced from Walker, 1985). (G) Diplichnites aenigma (traced from Dawson, 1873). (H) Diplichnites gouldi Type A (traced from Trewin and McNamara, 1994). (I) Eisenachichnus inaequalis (traced from Kozur, 1981). (J) Foersterichnus rossensis (traced from Pirrie, Feldmann \& Buatois, 2004). (K) Hamipes didactylus (traced from Getty, 2018). (L) Laterigradus lusitanicus (traced from de Carvalho et al., 2016). (M) Lithographus hieroglyphicus (traced from Hitchcock, 1858). (N) Maculichna varia (traced from Anderson, 1975a). (0) Merostomichnites narrangansettensis (traced from Packard, 1900). (P) Mirandaichnium famatinense (traced from Aceñolaza, 1978). (Q) Octopodichnus didactylus (traced from Gilmore, 1927). (R) Petalichnus multipartatus (Miller, 1880). (S) Pterichnus centipes (traced from Hitchcock, 1865). (T) Tasmanadia twelvetreesi (traced from Glaessner, 1957). (U) Umfolozia sinuosa (traced from Anderson, 1981). (V) Kouphichnium lithographicum (traced from Gaillard, 2011). (W) "Merostomichnites isp." (traced from Hanken \& Stormer, 1975). (X) Oniscoidichnus filiciformis (traced from Brady, 1947). (Y) Palmichnium antarcticum (traced from Braddy \& Milner, 1998). (Z) Paleohelcura tridactyla (traced from Gilmore, 1926). (AA) Protichnites septemnotatus (traced from Owen, 1852). (BB) Robledoichnus lucasi (traced from Kozur \& Lemone, 1995). (CC) Shalemichnus sittigi, half of trackway (traced from Kozur \& Lemone, 1995). (DD) Stiallia berriana (traced from Smith, 1909). (EE) Stiaria quadripedia (traced from Walker, 1985). (FF) 
Mitchellichnus ferrydenensis (traced from Walker, 1985). (GG) Keircalia multipedia (traced from Walker, 1985). (HH) Danstairia vagusa (traced from Walker, 1985). (II) Glaciichnium liebegastensis (traced from Walter, 1985). (J) Warvichnium ulbrichi (traced from Walter, 1985). (KK) Siskemia bipediculus (traced from Walker, 1985). (LL) Siskemia elegans (traced from Walker, 1985). (MM) Siskemia latavia (traced from Walker, 1985). (NN) Extant notostracan traces (traced from Knecht et al., 2009). (00) Extant crayfish trace in saturated, very fine sand (traced from Fairchild \& Hasiotis, 2011). (PP) SGDS 1290. 


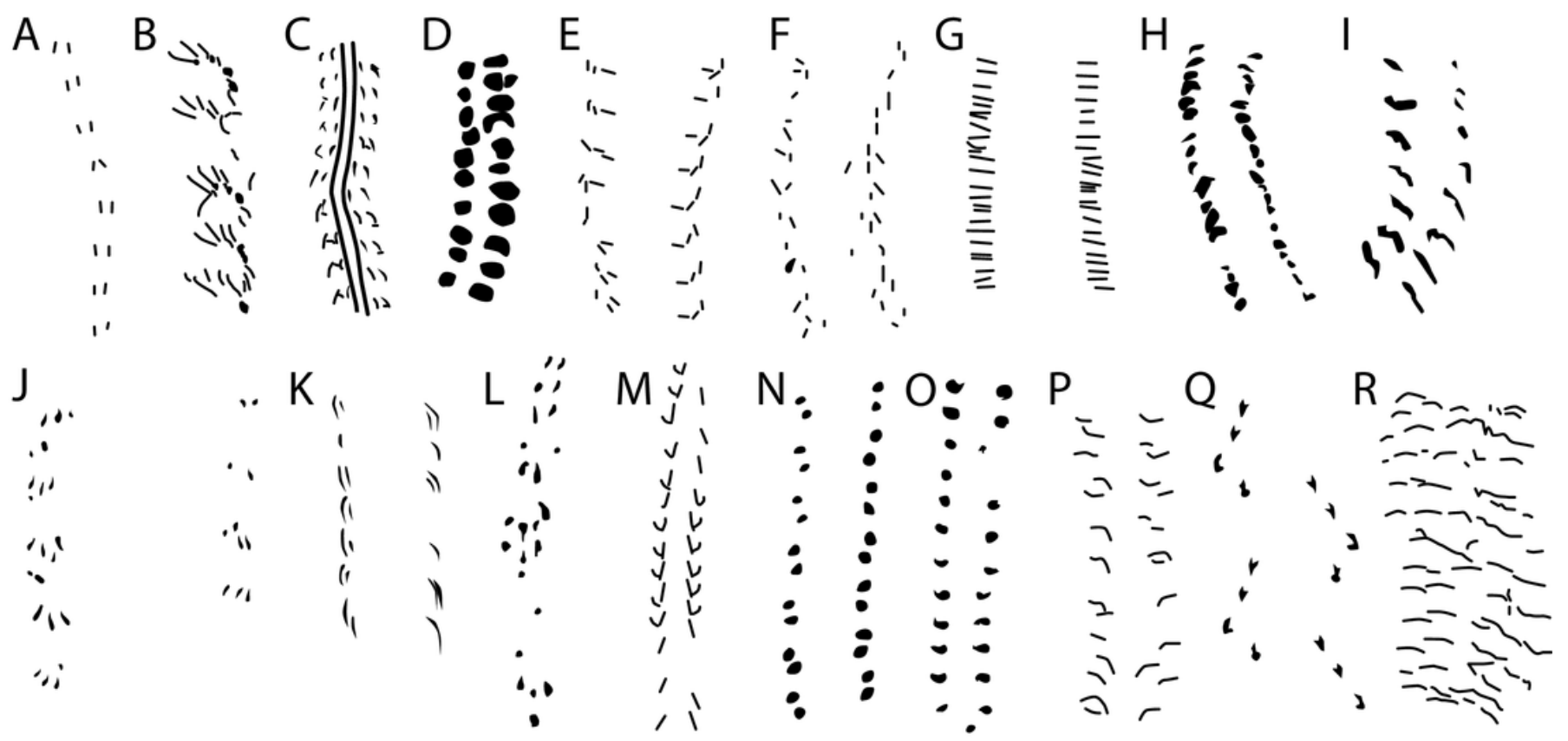

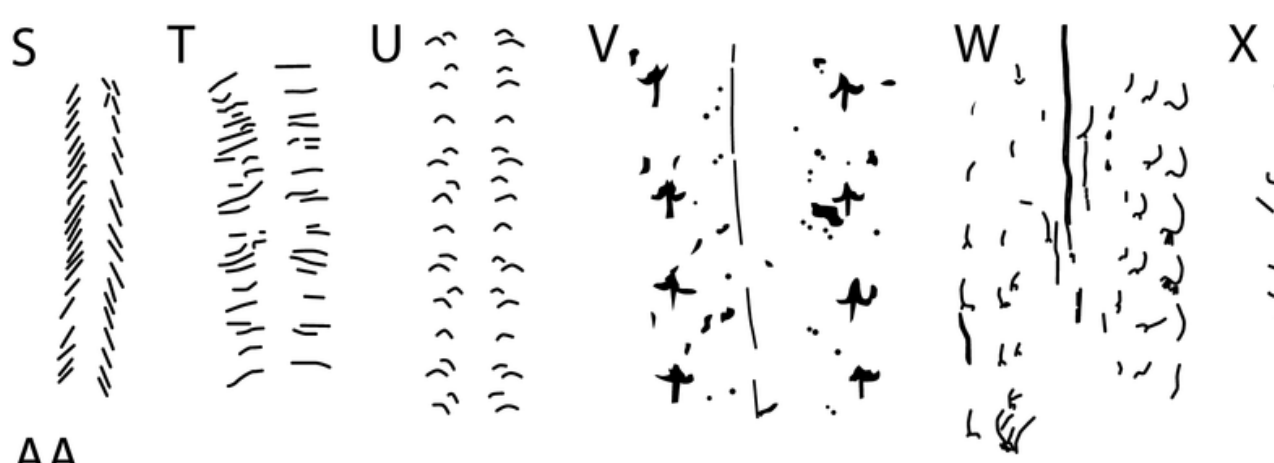

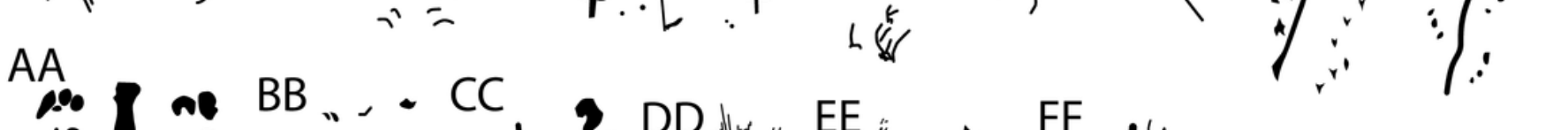

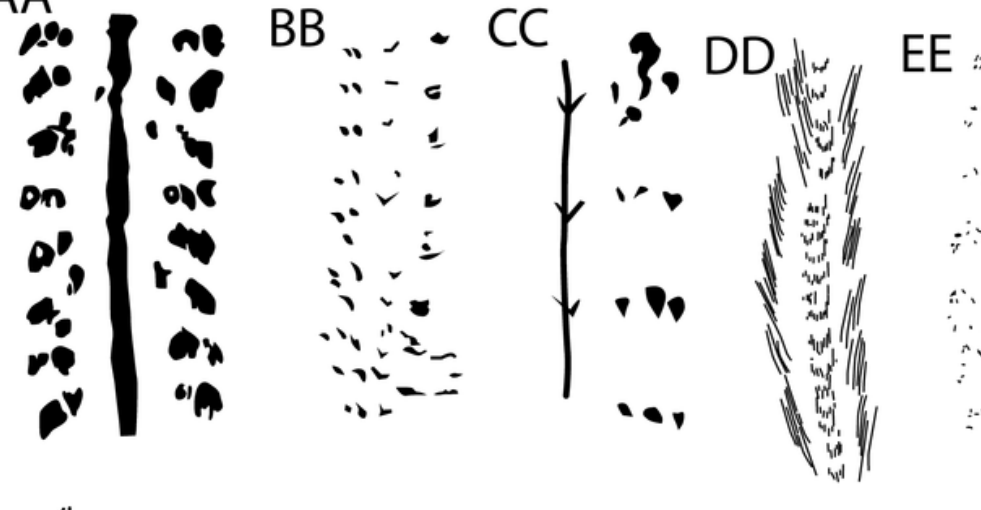

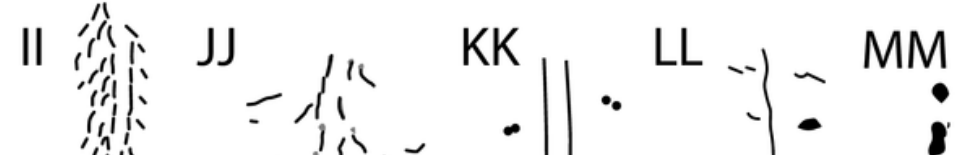

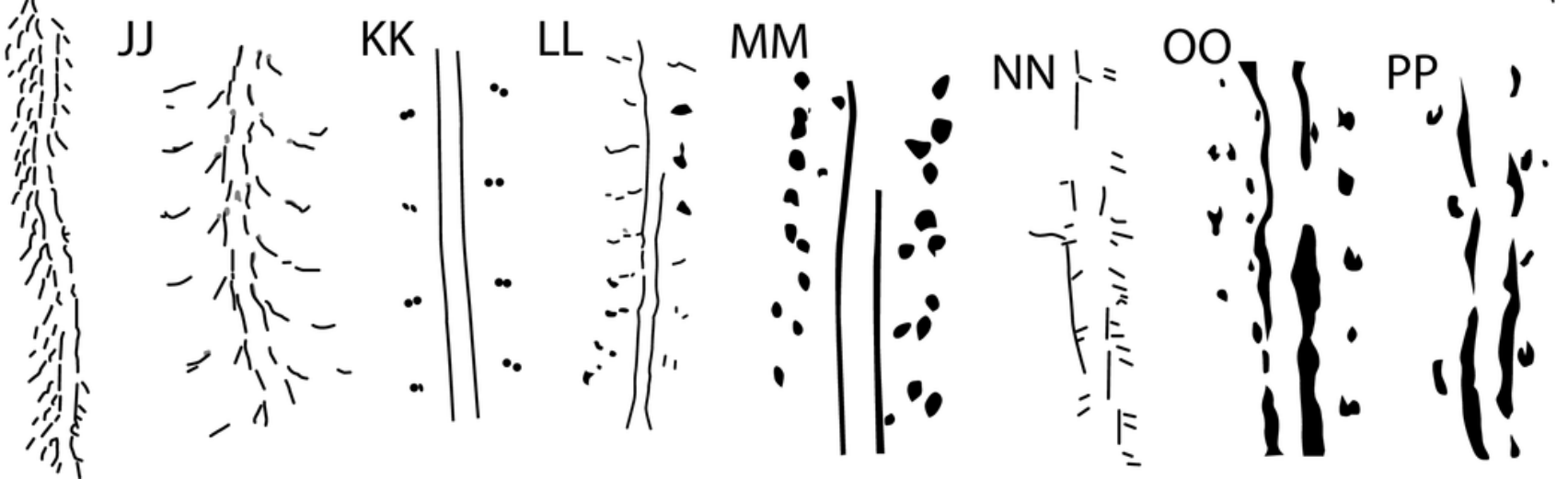




\section{Table $\mathbf{1}$ (on next page)}

Measurements (in mm) of arthropod locomotory trace fossil SGDS 1290.

Measurements in parentheses are approximated based on faint portions of paramedial impressions. 
1 Table 1: Measurements (in $\mathbf{m m}$ ) of arthropod locomotory trace fossil SGDS 1290.

2 Measurements in parentheses are approximated based on faint portions of paramedial

3 impressions.

4

\begin{tabular}{|c|c|c|c|c|c|c|c|}
\hline $\begin{array}{c}\text { Track } \\
\text { Position }\end{array}$ & Length & Width & $\begin{array}{c}\text { Impression } \\
\text { Internal } \\
\text { Width }\end{array}$ & $\begin{array}{c}\text { Impression } \\
\text { External } \\
\text { Width }\end{array}$ & $\begin{array}{c}\text { Track to } \\
\text { Impression } \\
\text { Distance }\end{array}$ & $\begin{array}{c}\text { Left } \\
\text { Impression } \\
\text { Width }\end{array}$ & $\begin{array}{c}\text { Right } \\
\text { Impression } \\
\text { Width }\end{array}$ \\
\hline L1 & 4.3 & 6.4 & 4.7 & 9.1 & 1.8 & 3.1 & 2.5 \\
\hline L2 & 4.2 & 5.7 & 5.9 & 9.5 & 1.5 & 2.6 & 2.2 \\
\hline L3 & 5.2 & 5.8 & 5.8 & 9.7 & 0.0 & 1.6 & 1.6 \\
\hline L4 & 3.2 & 5.6 & $(8.1)$ & $(11.2)$ & 0.0 & 1.9 & 0.0 \\
\hline R1 & 6.8 & 2.5 & 4.2 & 9.2 & 3.0 & 3.0 & 2.4 \\
\hline R2 & 4.6 & 5.3 & 5.4 & 8.8 & 4.2 & 2.7 & 0.0 \\
\hline R3 & 4.5 & 6.4 & 6.5 & 9.2 & 2.4 & 1.3 & 1.3 \\
\hline R4 & 3.0 & 5.8 & 6.9 & 10.6 & 0.0 & 0.0 & 3.0 \\
\hline
\end{tabular}

5

6 